Atmos. Chem. Phys. Discuss., 9, 22539-22579, 2009

www.atmos-chem-phys-discuss.net/9/22539/2009/

(C) Author(s) 2009. This work is distributed under

the Creative Commons Attribution 3.0 License.

This discussion paper is/has been under review for the journal Atmospheric Chemistry and Physics (ACP). Please refer to the corresponding final paper in $A C P$ if available.

\title{
Aerosol direct radiative forcing during Sahara dust intrusions in the central Mediterranean
}

Aerosol direct radiative forcing

M. R. Perrone et al.

Title Page

Abstract

Introduction

Conclusions

References

Tables

Figures

14

$\rightarrow 1$

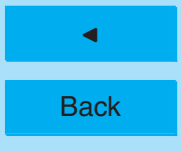

Close

Full Screen / Esc

Printer-friendly Version

Interactive Discussion

Published by Copernicus Publications on behalf of the European Geosciences Union.

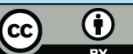




\section{Abstract}

The clear-sky, instantaneous Direct Radiative Effect (DRE) by all and anthropogenic particles is calculated during Sahara dust intrusions in the Mediterranean basin, to evaluate the role of anthropogenic particle's radiative effects and to get a better esti-

5 mate of the DRE by desert dust. The clear-sky aerosol DRE is calculated by a two stream radiative transfer model in the solar $(0.3-4 \mu \mathrm{m})$ and infrared $(4-200 \mu \mathrm{m}) \mathrm{spec}-$ tral range, at the top of the atmosphere (ToA) and at the Earth's surface (sfc). Aerosol optical properties by AERONET sun-sky photometer measurements and aerosol vertical profiles by EARLINET lidar measurements, both performed at Lecce $\left(40.33^{\circ} \mathrm{N}\right.$, $\left.18.10^{\circ} \mathrm{E}\right)$ during Sahara dust intrusions occurred from 2003 to 2006 year, are used to initialize radiative transfer simulations. Instantaneous values at $0.44 \mu \mathrm{m}$ of the real $(n)$ and imaginary $(k)$ refractive index and of the of aerosol optical depth (AOD) vary within the $1.33-1.55,0.0037-0.014$, and $0.2-0.7$ range, respectively during the analyzed dust outbreaks. Fine mode particles contribute from $34 \%$ to $85 \%$ to the AOD by

15 all particles. The complex atmospheric chemistry of the Mediterranean basin that is also influenced by regional and long-range transported emissions from continental Europe and the dependence of dust optical properties on soil properties of source regions and transport pathways are responsible for the high variability of $n, k$, and AOD values and of the fine mode particle contribution. Instantaneous net (solar+infrared) DREs that are negative as a consequence of the cooling effect by aerosol particles, span the - (32-10) $\mathrm{W} \mathrm{m}^{-2}$ and the - (44-20) $\mathrm{W} \mathrm{m}^{-2}$ range at the ToA and surface, respectively. The instantaneous net DRE by anthropogenic particles that is negative, varies within $-(13-8) \mathrm{W} \mathrm{m}^{-2}$ and $-(17-11) \mathrm{W} \mathrm{m}^{-2}$ at the ToA and surface, respectively. It represents from 41 up to $89 \%$ and from 36 up to $67 \%$ of the net DRE by all particles at the ToA and 25 surface, respectively. A linear relationship to calculate the DRE by natural particles in the solar and infrared spectral range is provided.

\section{Aerosol direct radiative forcing}

M. R. Perrone et al.

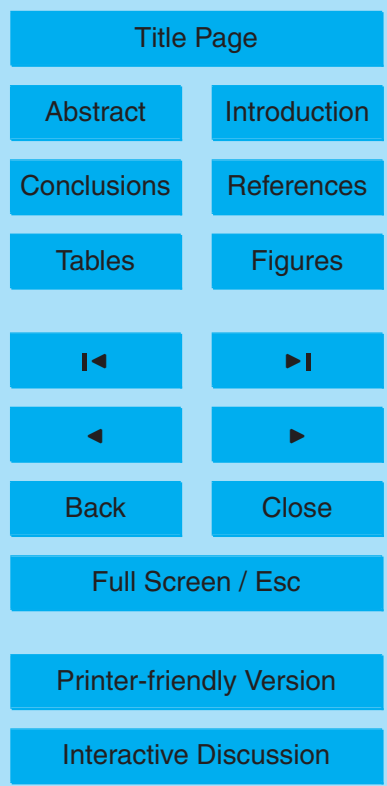




\section{Introduction}

Large quantities of African dust are carried into the Mediterranean basin every year and as a consequence mineral dust is among the major aerosol components over the Mediterranean. The direct radiative effect (DRE) by mineral dust is complex (Soko-

5 lik et al., 2001). Sign and magnitude of the dust DRE are controlled by dust optical properties, which depend on dust size distribution and dust refractive index. The latter depends on mineral composition and particle mixing state, which might vary regionally due to potentially different soil properties of dust source regions (Tegen, 2003). Desert dust absorbs at ultraviolet, visible, and infrared wavelengths and the African dust transport is driven by complex wind fields: the vertical structure of the dust layers reflects that complexity (e.g. Hamonou et al., 1999; di Sarra et al., 2001; De Tomasi et al., 2003). Hence, the presence of dust particles in the atmosphere can lead to either a cooling or a warming effect, depending on properties such as single-scattering albedo, altitude of the layer, and albedo of the underlying surface. According to Balkaaerosols will always warm the atmosphere column. Over dark surfaces such as oceans and deciduous forests, where surface albedo $(\alpha)$ is less than 0.15 , the effect of the mineral aerosols is similar to sulphates since it cools the atmospheric column. Over surface albedos in the intermediate range, $0.15<\alpha<0.30$, the sign of the forcing depends mainly on two factors, the size distribution and the mineralogical composition which both determine the single scattering albedo of the particles. Therefore the net radiative impact (sum of solar and long-wave) exhibits large regional variations, and this explains why the global mean is difficult to estimate: modeling studies and satellite retrievals do not agree on the amplitude and/or sign of the direct radiative perturbation 25 from dust (Balkanski et al., 2007).

Physical and optical properties of the Saharan dust aerosol measured by the Met Office C-130 during the Saharan Dust Experiment (SHADE) have been used by Haywood et al. (2003) to calculate the dust direct radiative effect. They found that the DRE at the

\section{Aerosol direct radiative forcing}

M. R. Perrone et al.
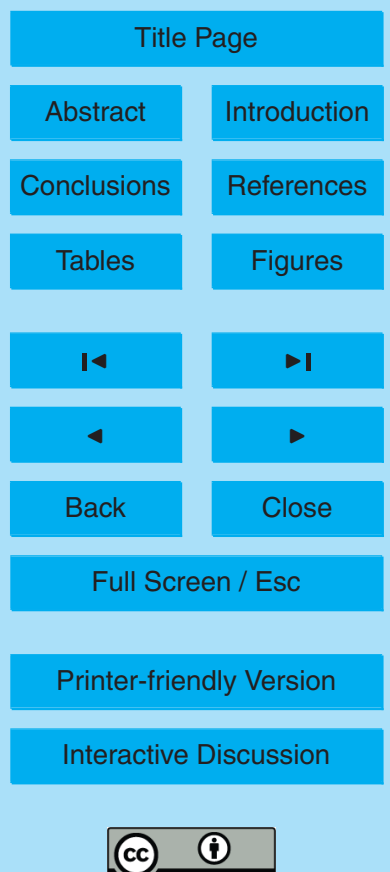
top of the atmosphere (ToA) ranged from -44 to $-129.2 \mathrm{~W} \mathrm{~m}^{-2}$ in the solar spectrum. Hence, their results suggested that the Saharan dust aerosol exerts the largest local and global DRE of all aerosol species and should be considered explicitly in global radiation budget studies. Results on the DRE of Saharan dust from measurements at 5 the Lampedusa Island, in two days of July 2002 (14 and 16) have also been reported by Meloni et al. (2003). They found that the instantaneous DRE over the 0.29-0.80 $\mu \mathrm{m}$ spectral range varied within the $-(1.2-6.2) \mathrm{W} \mathrm{m}^{-2}$ and the $-(12.3-25.0) \mathrm{W} \mathrm{m}^{-2}$ range at the ToA and surface, respectively.

The instantaneous DRE by all (anthropogenic plus natural) and anthropogenic 10 aerosols from measurements at Lecce $\left(40.33^{\circ} \mathrm{N}, 18.10^{\circ} \mathrm{E}\right)$, in south-east Italy, during Sahara dust intrusion events, monitored from 2003 to 2006 year, is investigated in this paper to further contribute to the characterization of the direct radiative forcing by desert dust over the central Mediterranean. Instantaneous DRE values are calculated by a two-stream radiative transfer model (Tafuro et al., 2007; Bergamo et al., 2008a, b) in the solar $(0.3-4 \mu \mathrm{m})$ and infrared $(4-200 \mu \mathrm{m})$ spectral range, at the top of the atmosphere (ToA) and at the surface (sfc): the ToA forcing is important to local and global radiation budgets, the sfc-forcing is important to surface heating and water evaporation (Bates et al., 2006).

Section 2 provides a brief description of the two stream radiative transfer model and

of input data. Section 3 provides a detailed analysis of the dust outbreak monitored at Lecce on 22 June 2006. Main results on instantaneous aerosol properties and corresponding DREs referring to all investigated dust outbreaks are analyzed and discussed in Sect. 4. Summary and conclusion are in Sect. 5.

\section{The two-stream radiative transfer model and input data}

A detailed description of the used two-stream, radiative-transfer model is given in Tafuro et al. (2007). The two stream method (e.g. Meador and Weaver 1980) provides radiative fluxes at the boundary of homogeneous plane-parallel layers. Twenty

\section{Aerosol direct radiative forcing}

M. R. Perrone et al.

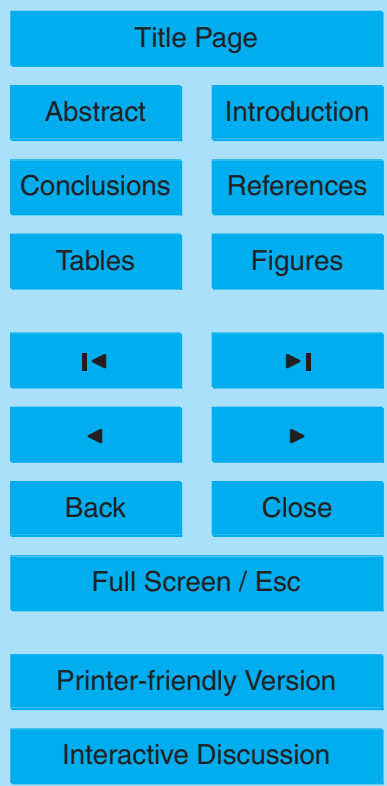


homogeneous plane-parallel atmospheric layers are used in our model to account for the changes with altitude of atmospheric parameters and components (e.g. pressure, temperature, gases, and particle distributions), and radiative fluxes are determined in the solar $(0.3-4 \mu \mathrm{m})$ and infrared $(4-200 \mu \mathrm{m})$ spectral region. In particular, eight so$5 \operatorname{lar}(0.35,0.45,0.55,0.65,1.00,1.6,2.2$, and $3.0 \mu \mathrm{m})$ and twelve infrared $(4.25,5.35$, $6.25,7.35,8.75,10.30,11.75,13.90,17.20,24.30,37.00$, and $80.00 \mu \mathrm{m})$ subbands are considered to properly account for the spectral dependence of atmospheric particle properties: the optical properties (extinction, single-scattering albedo, and asymmetry factor) of the atmospheric particles remain constant in each of the 20 subbands. 10 Absorption of trace gases $\left(\mathrm{H}_{2} \mathrm{O}, \mathrm{O}_{3}, \mathrm{CO}_{2}, \mathrm{CO}, \mathrm{N}_{2} \mathrm{O}\right.$, and $\left.\mathrm{CH}_{4}\right)$ is represented by I exponential terms in each of the 20 spectral subbands, with / varying within the 1-12 range. Thus, 20 applications of the radiative transfer model are required to account for the solar and infrared spectral dependence of each trace gas (Tafuro et al., 2007).

Input data include instantaneous size distributions and real and imaginary refractive 15 indices from AERONET sun-sky photometer measurements (Holben et al., 1998) performed at Lecce during Sahara dust intrusion events that have occurred from 2003 to 2006 year. Cloud-screened and quality-assured AERONET retrievals (level 2.0) from the version 2 (V2) inversion algorithm are used in this study. Then, MIE calculations (assuming a spherical particle shape) are applied to translate the AERONET data on size, concentration and refractive indices into AODs (a measure of the magnitude of the aerosol extinction due to scattering and absorption), single scattering albedo (SSA) values (a measure of the relative importance of absorption and scattering), and asymmetry-factor $(g)$ values (a measure of the angular distribution of the scattering radiation). AOD, SSA, and $g$ represent the major used parameters in aerosol DRE 25 simulations.

Surface albedo values are based on the ones assumed for Lecce in the AERONET inversion code at the wavelengths corresponding to sky radiance measurements. In particular, AERONET $\alpha$ values at 0.44 and $0.675 \mu \mathrm{m}$ are averaged to get the model $\alpha$ values in the solar $(0.3-0.7 \mu \mathrm{m})$ spectral range. Whereas, AERONET surface albedo

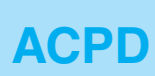

9, 22539-22579, 2009

\section{Aerosol direct radiative forcing}

M. R. Perrone et al.

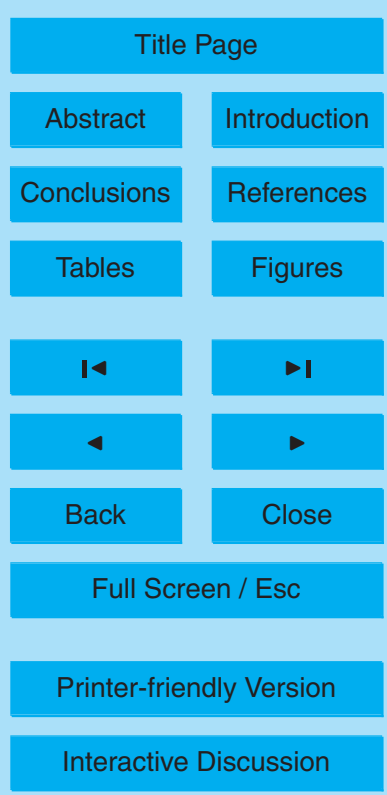


values at 0.87 and $1.02 \mu \mathrm{m}$ are averaged to get the model surface albedo at nearinfrared wavelengths $(0.7-5 \mu \mathrm{m})$. A surface emissivity of 0.96 is assumed in the farinfrared.

Lidar measurements performed within the European Aerosol Research Lidar 5 Network-EARLINET (e.g. Matthias et al., 2004) are used to characterize the aerosol vertical distribution. Then, radiosonde measurements (see also http://raob.fsl.noaa. gov) at the meteorological station of Brindisi that is $40 \mathrm{~km}$ north-west of Lecce are used to define vertical profiles of density, pressure, temperature, and water vapor from 1 up to $20 \mathrm{~km}$ altitude. Density, pressure, temperature, and water vapor values retrieved by 10 the Brindisi radio-sondes at the surface are replaced with corresponding values more appropriate for Lecce (Tafuro et al., 2007). Above $20 \mathrm{~km}$ of altitude, vertical profiles of density, pressure, temperature, and water vapor are extended with corresponding midlatitudes standard atmosphere data provided by the Air Force Geophysics Laboratory (AFGL) for autumn-winter and spring-summer months. The Rayleigh scattering due to 15 atmospheric molecules is taken into account (Tafuro et al., 2007).

Vertical profiles of oxygen, ozone, and well mixed trace-gases $\left(\mathrm{N}_{2} \mathrm{O}, \mathrm{CO}_{2}, \mathrm{CO}\right.$ and $\mathrm{CH}_{4}$ ) are prescribed by the US Air Force Geophysics Laboratory (AFGL) standard atmosphere for mid-latitude $\left(30-60^{\circ} \mathrm{N}\right)$ summer and winter with interpolations for the transitional seasons. Trace-gas concentrations in conjunction with pre-defined absorp-

\section{Dust outbreak of 22 June 2006 and aerosol DREs}

7-day analytical back trajectories by NASA GSFC (http://croc.gsfc.nasa.gov/aeronet/ index.html), true-color satellite images by the MODerate Resolution Imaging Spectroradiometer - MODIS (http://modis.gsfc.nasa.gov/; King et al., 1992), AERONET products as the Angstrom coefficient $(\AA)$ and the fine mode fraction, and polarization-sensitive lidar measurements have all been used to detect Sahara dust intrusion events over the Mediterranean and in particular at the monitoring site (e.g. Tafuro et al., 2006, 2008).

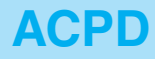

9, 22539-22579, 2009

\section{Aerosol direct radiative forcing}

M. R. Perrone et al.

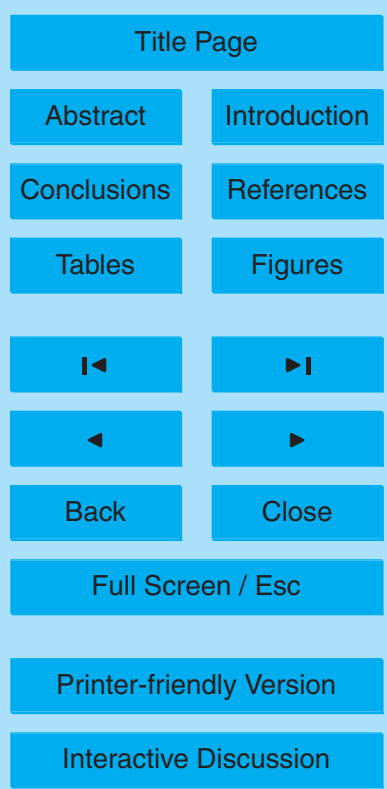


Hence, dusty days have been selected in accordance with different dust event markers, as it is outlined in Sect. 3.1.

\subsection{Aerosol properties and direct radiative effects on 22 June}

In this section we analyze in more detail, as an example, the instantaneous DRE by 5 aerosol particles monitored at Lecce during the dust intrusion event of 22 June 2006. Several dust intrusion events have occurred over the Mediterranean basin on the second half of June 2006, as true-color MODIS satellite images reveal. Figure 1 shows the 7-day analytical back trajectories for the air masses reaching Lecce on 22 June. Analytical back trajectories are provided by NASA for each AERONET site, at eight distinct 10 arrival pressure levels $(950,850,700,500,400,300,250$, and $200 \mathrm{hPa})$ and at two arrival times (00:00 and 12:00 UTC). The trajectories are based on a kinetic trajectory analysis using NASA GMAO assimilated gridded data. Figure 1a shows the pathways of the $950,850,700$, and $500 \mathrm{hPa}$ back trajectories that reach Lecce on 22 June at 12:00 UTC. The altitude of each back trajectory as a function of time is shown on

15 Fig. 1b. We observe from Fig. 1a that the 700 and $500 \mathrm{hPa}$ back trajectories originate over Mauritania and south-east Algeria, respectively and travel over north-west Africa before reaching the monitoring site. Conversely, the 950 and $850 \mathrm{hPa}$ back trajectories cross Tunisia and north-east Algeria but, they spend a large fraction of the days over the central Mediterranean basin.

$20 \quad$ Figure $2 \mathrm{a}-\mathrm{e}$ shows the aerosol backscatter coefficient profile $\beta(z)$ retrieved from lidar measurements performed on 22 June at different day hours (UTC). A polarization sensitive lidar system whose light source is a XeF excimer laser operating a $0.351 \mu \mathrm{m}$ has been used to retrieve $\beta(z)$ profiles of Fig. 2 (De Tomasi et al., 2006). Grey dotted lines in Fig. 2 represent vertical profiles of the depolarization ratio $(\delta)$, which is the ratio between the total cross-polarized backscatter coefficient and the total polarization preserving backscatter coefficient. $\delta$ takes a value of 0.014 in a pure molecular atmosphere and generally higher values in presence of non spherical particles such as desert dust particles (e.g. Tafuro et al. 2006). Figure 2a shows that the aerosol

Aerosol direct radiative forcing

M. R. Perrone et al.

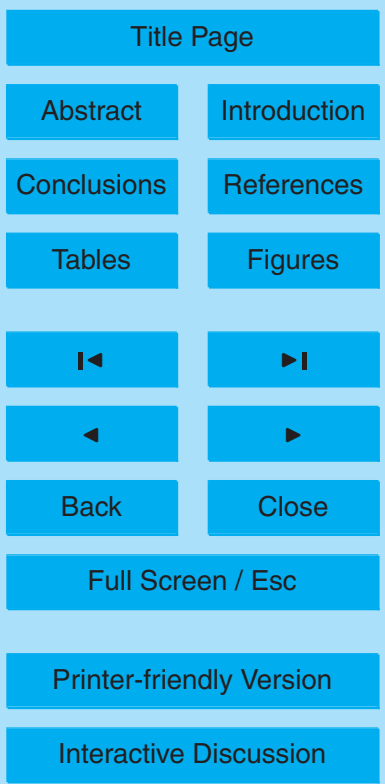


layer extends up to $\sim 2.7 \mathrm{~km}$ at the early morning. Conversely, lidar measurements performed from 10:28 to 11:32 UTC show that the aerosol burden extends up $\sim 6 \mathrm{~km}$ (Fig. 2b). Aerosols up to $\sim 6 \mathrm{~km}$ have been detected by the lidar at least until 16:37 UTC, in accordance with Fig. 2. Dotted lines in Fig. 2a, b show that the depolarization ratio is 5 of about 0.07 from about 0.5 to $2 \mathrm{~km}$ and of about 0.08 from 0.5 to $5.5 \mathrm{~km}$, respectively. Depolarization ratio uncertainties are lower than $10 \%$. $\delta$ values of Fig. $2 \mathrm{a}, \mathrm{b}$ allow inferring the presence of non spherical particles and hence, of desert dust particles, in accordance with the discussion reported above. Moreover, the poor dependence of $\delta$ values on altitude revealed by Fig. $2 \mathrm{a}, \mathrm{b}$, suggests that non-spherical particles are well 10 mixed in the whole aerosol layer. It is worth noting from Fig. $2 c$ that rather high depolarization ratios ( $\cong 0.4)$ are detected by lidar measurements at $4.5 \mathrm{~km}$ of altitude, from $11: 47$ to $12: 51$ UTC (Fig. 2c). The larger $\beta(z)$ and $\delta(z)$ values revealed by Fig. 2c are likely due to a larger advection over the monitoring site of air masses from the Sahara desert. In fact, the air masses advected over Lecce above $2 \mathrm{~km}$ of altitude have their 15 origin over north-west Sahara in accordance with Fig. 1a. The high variability within few hours of the aerosol column burden and of the aerosol microphysical properties revealed by Fig. 2 is typical of Sahara dust intrusions over the Mediterranean (e.g. De Tomasi et al., 2003; Tafuro et al., 2008; Pavese et al., 2009).

In addition to back trajectories and lidar measurements, aerosol products by 20 AERONET sun/sky photometer measurements also support the presence of Sahara dust particles over Lecce. Figure 3 shows the columnar volume size distribution retrieved from AERONET measurements at 15:31 UTC (dotted line) and at 16:27 UTC (solid line). The bimodal structure of Fig. 3 spectra indicates that along with fine mode particles, which are mainly of anthropogenic origin, coarse-mode particles also signif25 icantly contribute to the aerosol burden, which increases from 15:31 to 16:27 UTC, in accordance with lidar measurements (Fig. 2d,e). The bimodal structure of the columnar volume size distributions of Fig. 3 is generally observed at Mediterranean AERONET sites during Sahara dust outbreaks, as it has been shown by Tafuro et al. (2006). The AERONET Angstrom coefficient, computed from AOD values at 0.44 and

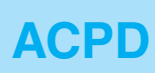

9, 22539-22579, 2009

\section{Aerosol direct radiative forcing}

M. R. Perrone et al.

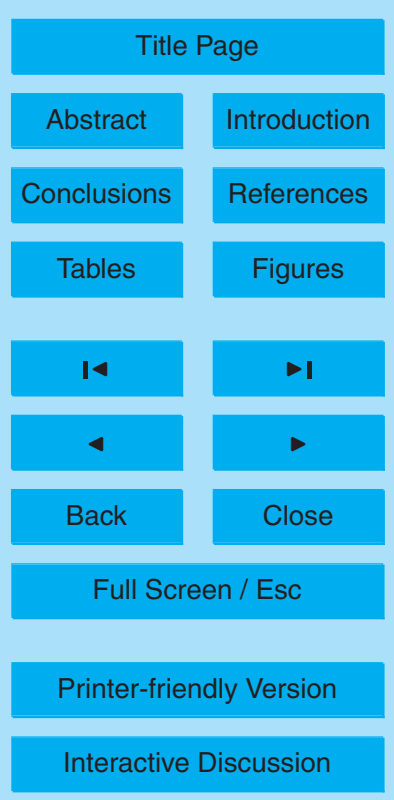

22546 
$0.87 \mu \mathrm{m}$, which takes the value of 0.46 and 0.52 at 15:31 and 16:27 UTC, respectively, also supports the advection of dust particles over Lecce. As it is well known $\AA$ is the best marker to infer the aerosol type. Typical $\AA$ values range from 1.5 for aerosol dominated by accumulation mode particles, to nearly zero for large dust particles (e.g.

5 Tafuro et al., 2006).

Instantaneous values at $0.44 \mu \mathrm{m}$ of the real $(n)$ and imaginary $(k)$ refractive index retrieved from AERONET measurements at 15:31 and at 16:27 UTC are given in Table 1 in addition to $\alpha$ values calculated from AERONET data.

The columnar volume size distributions of Fig. $3, n, k$, and $\alpha$ values from Table 1 , 10 and the AOD fraction vertical profiles retrieved by the $\beta(z)$ vertical profiles of Fig. $2 \mathrm{e}, \mathrm{d}$, have been used to calculate by the two-stream radiative transfer model the clear-sky instantaneous aerosol DRE at 15:31 and 16:27 UTC, respectively of 22 June 2006.

Instantaneous DRE values by the whole aerosol $\left(\mathrm{DRE}_{t}\right)$ at solar and infrared (IR) wavelengths, and at the ToA and surface, respectively are given in Table 2, in addition to the surface flux $\left(F_{\text {sfc }}\right)$ in the solar and IR spectral range, respectively.

Simulated surface net-fluxes (open dots) are compared in Fig. 4 to broadband netflux measurements at the surface (solid line). A net radiation transducer (p056 RADNT, by SIAP+MICROS S.r.l., Italy) characterized by $1.5 \%$ accuracy, is routinely used at the ISAC-CNR Department of Lecce (www.basesperimentale.le.isac.cnr.it) to monitor broadband net-fluxes for the $0.3-30 \mu \mathrm{m}$ spectral range, with two hemispheric (up and down) sensors. The net radiation transducer is located few hundred meters away from the AERONET sun/sky radiometer site. Figure 4 reveals that measured net-fluxes are in satisfactory accordance with simulated values: simulated net-fluxes are 15 and $5 \%$ larger than measured net fluxes at 15:31 and 16:27 UTC, respectively. We believe that these last results demonstrate the appropriateness of model input and output.

Table 2 shows that aerosol DREs at solar wavelengths are negative at the ToA and surface since aerosol particles determine a planetary and surface cooling. In particular, the DRE at the surface by all particles $\left(\mathrm{DRE}_{t, \mathrm{sfc}}\right)$ is 2.7 and 1.5 larger than that at the ToA at 15:31 and 16:27 UTC, respectively, in accordance to previous studies

\section{Aerosol direct radiative forcing}

M. R. Perrone et al.

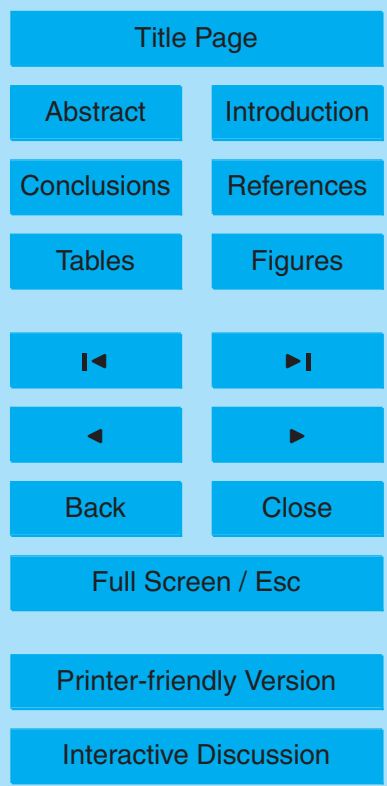

Interactive Discussion

\section{7}


(e.g. Tafuro et al., 2007; Bergamo et al., 2008b; Meloni et al., 2003). Aerosol DREs at infrared wavelengths are positive and in particular, the aerosol IR-DRE offsets the solar-DRE by 8.5 and of $17 \%$ at the ToA and surface, respectively at $15: 31$ UTC. While, the aerosol IR-DRE offsets the solar-DRE by $7.2 \%$ and of $22 \%$ at the ToA and surface, 5 respectively at 16:27 UTC. These last results reveal the significant role of the IR-DRE during dust intrusion events.

\subsection{Direct radiative effects by anthropogenic particles on 22 June}

Volume size distributions of Fig. 3 indicate that along with coarse-mode particles that are mainly due to Sahara dust, fine-mode particles also contribute to the aerosol burden of 22 June. Fine-mode particles are mainly due to the anthropogenic aerosol. The anthropogenic aerosol contribution is associated in this paper with the number concentration of fine-mode aerosol $N_{f}(r)$ provided by AERONET, in accordance to Bergamo et al. (2008a). Potential anthropogenic contributions to the coarse-mode aerosol are ignored. In particular, only a fraction $f$ of $N_{f}(r)$ is considered of anthropogenic origin in accordance with the following relationship

$N_{a}(r)=f \times N_{f}(r)$

where $N_{a}(r)$ is the number concentration of anthropogenic-only submicron aerosol particles. Monthly $f$-values relating to Lecce are given by Bergamo et al. (2008a) and are considered constant with particle size in the submicron fraction. $f$-values are based on

LMDzT3.3 (Reddy et al., 2005) global model-simulations (Schulz et al., 2006). In particular, inventories for global emissions of aerosols and pre-cursor gases for the years 2000 (current conditions) and 1750 (pre-industrial conditions) have been used in the General Circulation Model LMDzT3.3 to calculate $f$-values (Dentener et al., 2006; Stier et al., 2007).

MIE calculations are applied to translate the data on number concentration of anthropogenic aerosols (Eq. 1) into aerosol optical depth, single-scattering albedo, and

\section{Aerosol direct radiative forcing}

M. R. Perrone et al.

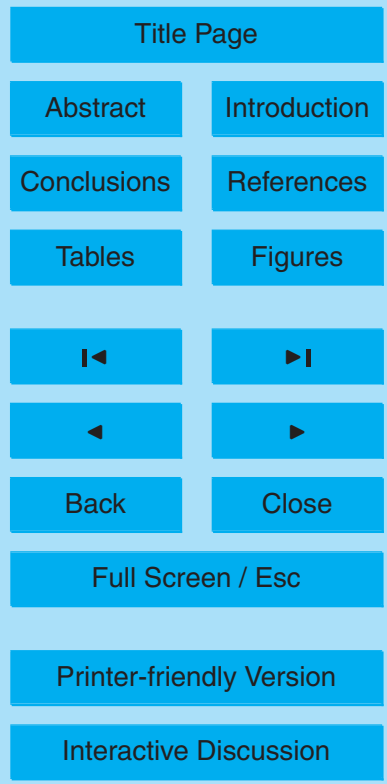


asymmetry factor for anthropogenic particles: $\mathrm{AOD}_{a}, \mathrm{SSA}_{a}$, and $g_{a}$, respectively. Refractive indices are not considered dependent on particle size. A discussion on this last assumption is given in Bergamo et al. (2008a). $\mathrm{AOD}_{a}$ values at $0.55 \mu \mathrm{m}$ by MIE calculations and for $f=0.73$ are given in Table 2 in addition to $A_{O D}$ values at $0.55 \mu \mathrm{m}$.

5 It is worth noting that $38 \%$ of the $A D_{t}$ is due to anthropogenic particles at $15: 31$ and 16:27 UTC, respectively.

Simulated DRE values by anthropogenic particles $\left(\mathrm{DRE}_{a}\right)$ in the solar and infrared (IR) spectral range, and at the ToA and surface are given in Table 2. The solar ToA-DRE by anthropogenic particles $\left(\mathrm{DRE}_{a, \mathrm{ToA}}\right)$ is 50 and $44 \%$ of the solar-DRE by all particles 10 (DRE $\left._{t, \text { ToA }}\right)$ at 15:31 and 16:27 UTC, respectively. Conversely, 30 and $36 \%$ of the solar$\mathrm{DRE}_{t, \mathrm{sfc}}$ is due to anthropogenic particles at 15:31 and 16:27 UTC, respectively. The IR-DRE by anthropogenic particles is negligible at the ToA, whereas at the surface, it represents 11 and $14 \%$ of the of the IR-DRE $t$,sf at 15:31 and 16:27 UTC, respectively. In conclusion, the results listed above highlight the significant role of anthropogenic 15 particles during Sahara dust intrusion in the Mediterranean and allow inferring that the net (solar+IR) DRE by desert dust particles is less than 55 and $60 \%$ of the net DRE by all aerosol at the ToA and surface, respectively on 22 June 2006.

\section{Methodology and results of 2003-2006 dust outbreaks}

The dust events that have been selected to study clear-sky aerosol DREs are listed in

20 Table 1, where AERONET instantaneous values of AOD, $n$, and $k$ at $0.44 \mu \mathrm{m}$, of the Angstrom coefficient $(0.44 \mu \mathrm{m} / 0.87 \mu \mathrm{m})$, and of the solar surface albedo $(\alpha)$ are also given. Analytical back trajectories, true-color MODIS images, AERONET products, and polarization-sensitive lidar measurements have been used to infer dust intrusion events over Lecce, as we have outlined in the previous paragraph.

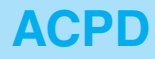

9, 22539-22579, 2009

\section{Aerosol direct radiative forcing}

M. R. Perrone et al.

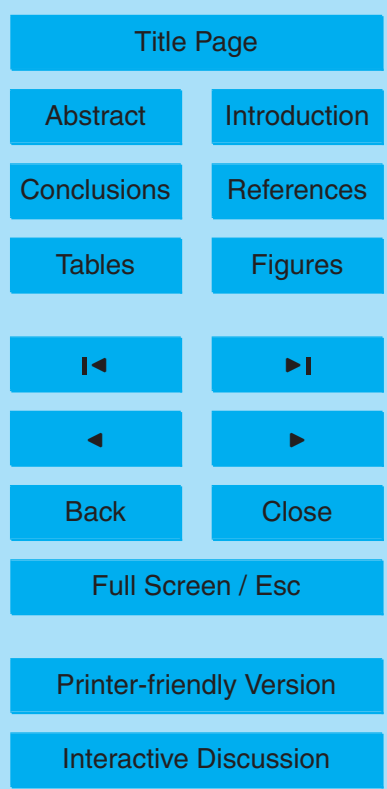




\subsection{Analysis of aerosol properties by AERONET during Sahara dust intrusions}

Instantaneous columnar size distributions and $n$ and $k$ values by AERONET are used in the radiative transfer code to define aerosol properties. Figure $5 \mathrm{a}$ shows by dotted lines the instantaneous columnar volume size distributions retrieved by AERONET

5 measurements performed on the selected dusty-days, to highlight main features of dusty-day volume size distributions. The largest coarse mode peak at $\sim 2.5 \mu \mathrm{m}$ has been retrieved from measurements performed on 17 July, 2003 at 04:59 UTC. The black line in Fig. 5a represents the mean columnar volume size distribution obtained by averaging all instantaneous volume distribution profiles. Vertical error bars in Fig. 5a 10 represent \pm 1 standard deviation from the average value and indicate the volume size distribution variability. The significant role of coarse-mode particles in dusty-days is clearly pointed-out by Fig. $5 \mathrm{a}$, which reveals that the mean coarse mode distribution peaks at $\cong 2.2 \mu \mathrm{m}$. However, along with coarse-mode particles, fine-mode particles also significantly contribute to the aerosol burden.

15 Instantaneous $\AA$ values versus $A O D$ s at $0.44 \mu \mathrm{m}$, retrieved during dusty-days are plotted in Fig. 5b. Different symbols are used to characterize different dusty-days. $\AA$ represents a good marker of dust outbreaks, as we have mentioned. We observe that instantaneous $\AA$ values span the $1.5-0.23$ range. Nevertheless, data points relating to a given day vary within a rather small range. This result may indicate that aerosol microphysical properties are quite dependent on the dust event and less on the aerosol property changes during the day. Figure $5 b$ also shows that $\AA$ values and variability range decrease as the $A O D$ increases. Hence, coarse mode particles are responsible for the higher AODs monitored during dust events. While, the contribution of fine mode particles of local origin and/or long-range transported is responsible for the high $25 \AA$ values obtained during low-AOD dusty-days. Figures $6 \mathrm{a}$ and $6 \mathrm{~b}$ show the scatterplot of $n$ and $k$ values versus the AOD at $0.44 \mu \mathrm{m}$, respectively. $n$ and $k$ instantaneous values vary within the $1.33-1.55$ and $0.0037-0.014$ range, respectively during the monitored dust outbreaks and are quite dependent on the aerosol burden in accordance

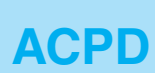

9, 22539-22579, 2009

\section{Aerosol direct radiative forcing}

M. R. Perrone et al.

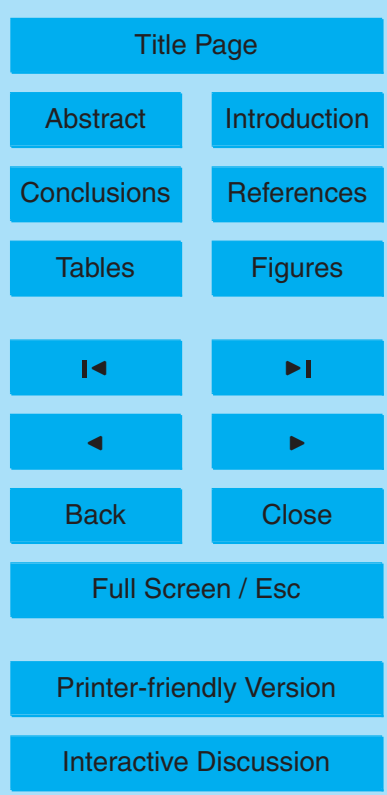


with Fig. 5b. The columnar averaged value $\pm 1 \mathrm{SD}$ of $n$ and $k$ is: $\langle n\rangle=1.48 \pm 0.01$ and $\langle k\rangle=0.007 \pm 0.002$ at AODs $>0.45$. Whereas, $\langle\AA\rangle=0.33 \pm 0.07$ for AODs $>0.45$ (Fig. 5b). These last results are in accordance with corresponding mean values reported by Tafuro et al. (2006). AERONET sun/sky photometer measurements per5 formed at five different sites of the central Mediterranean during strong Saharan dust outbreaks have been used by Tafuro et al. (2006) to calculate $\AA, n$ and $k$ mean values. Hence, the $\langle n\rangle$ and $\langle k\rangle$ values of this paper at AODs $(0.44 \mu \mathrm{m})>0.45$, further more contribute to the definition of the mean aerosol properties during large dust intrusion events in the Mediterranean.

\subsection{Simulated aerosol properties at $0.55 \mu \mathrm{m}$}

Instantaneous $\mathrm{AOD}_{t}, \mathrm{SSA}_{t}$, and $g_{t}$ values at $0.55 \mu \mathrm{m}$, recomputed from AERONETderived aerosol size distributions and refractive indices, are plotted in Fig. $7 a-c$, respectively as a function of the fine mode fraction $\eta$, i.e. the ratio between the fine-mode and the total aerosol optical depth at $0.55 \mu \mathrm{m}$. Figure $7 \mathrm{a}$ shows that $\mathrm{AOD}_{t}$ values span the 0.19-0.64 range and increase as $\eta$ values decrease, in accordance with Fig. $5 \mathrm{~b}$. $g_{t}$ values that span the $0.61-0.70$ range also increase as $\eta$ values decrease (Fig. 7c). Conversely, $\mathrm{SSA}_{t}$ values span the $0.87-0.95$ range without any significant dependence on $\eta$. Instantaneous $\mathrm{SSA}_{t}$ values of this study are in satisfactory accordance with the ones provided by Meloni et al. (2003), whereas Lecce's $g_{t}$ values are smaller than the ones retrieved at Lampedusa, where the contribution of coarse mode particles is on average larger being Lampedusa closer to the Africa coast.

The anthropogenic aerosol contribution is associated with a fraction $f$ of the submicron size particles, in accordance with the discussion reported in Sect. 3.2. The $f$ value has been set equal to 0.73 and 0.80 for the June and July month, in accordance to Bergamo et al. (2008a). Then, MIE calculations are applied to translate the number concentration of anthropogenic aerosols into $\mathrm{AOD}_{a}, \mathrm{SSA}_{a}$, and $g_{a}$. Figure $8 \mathrm{a}$ shows the scatterplot of the $A O D_{a} / A O D_{t}$ ratio versus the $A O D_{t}$. The $A O D_{a} / A O D_{t}$ ratio that is quite dependent on dust-day varies from 0.27 up to 0.65 and allows inferring the

\section{Aerosol direct radiative forcing}

M. R. Perrone et al.

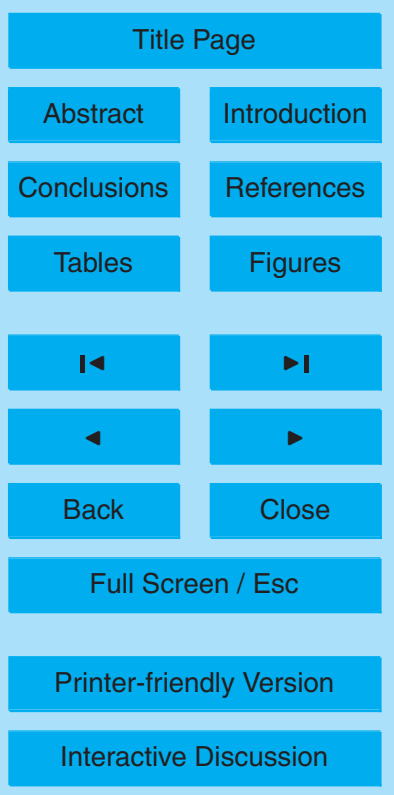


significant role of anthropogenic particles in Mediterranean dust events. It is also worth noting from Fig. $8 \mathrm{a}$ that the contribution of anthropogenic particles decreases with $\mathrm{AOD}_{t}$. Figure $8 \mathrm{~b}, \mathrm{c}$ show the scatterplot of $\mathrm{SSA}_{a}$ versus $\mathrm{SSA}_{t}$ and of $g_{a}$ versus $g_{t}$, respectively. The comparison of Fig. 8 data to the ones reported by Bergamo et al. 5 (2008a) allows inferring that $\mathrm{AOD}_{a} / \mathrm{AOD}_{t}$ ratios, and $\mathrm{SSA}_{a}$, and $g_{a}$ values of this study are typical of Mediterranean costal sites.

\subsection{Aerosol vertical distribution on dusty days}

Lidar measurements at the closest time of AERONET measurements have been used to retrieve the vertical profile of the AOD fraction used in the aerosol radiative forcing calculations. Figure 9 shows vertical profiles of all instantaneous dusty-day AOD fractions (grey dotted lines). The huge layer from about 5 to $8 \mathrm{~km}$ has been detected by the lidar on 24 June 2003. The solid line in Fig. 9 represents the mean vertical profile of the AOD fraction. Horizontal error bars represent \pm 1 standard deviation from the average value and indicate the AOD fraction variability. The high variability in time and space of the aerosol vertical distribution revealed by Fig. 9 is typical of Sahara dust intrusion events (e.g. Pavese et al., 2009). Aerosol particles up to $8 \mathrm{~km}$ have been monitored by the lidar during the analyzed dusty days.

\subsection{Instantaneous DREs by all particles on dusty days}

Clear-sky, instantaneous DREs by all aerosol particles relating to the selected dustydays (Table 1) are analyzed in this section. Simulated surface net (solar+IR) fluxes are plotted in Fig. 10a as a function of surface net-flux measurements performed at Lecce by a net radiation transducer (p056 RADNT). We observe from Fig. 10a that instantaneous experimental and simulated fluxes are quite well correlated. Hence, both the correlation coefficient $(r=95 \%)$ and the slope $(1.07 \pm 0.04)$ of the regression line fitting the data points demonstrate the appropriateness of input and output data of the used radiative transfer model. Figure $10 \mathrm{~b}$ shows the scatterplot of the solar (0.3-

\section{Aerosol direct radiative forcing}

M. R. Perrone et al.

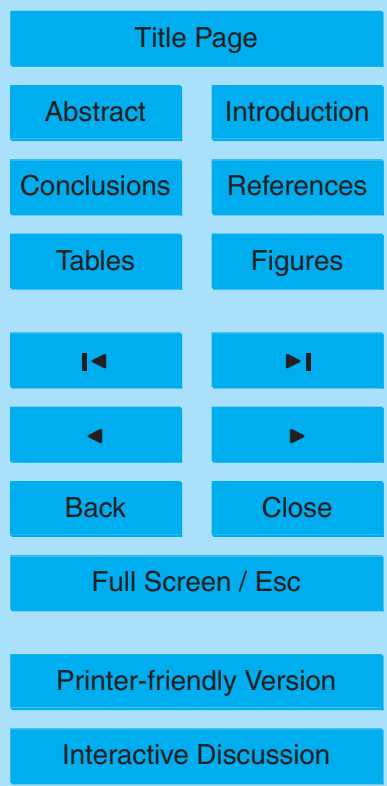

\section{2}


$4.0 \mu \mathrm{m})$ flux at the surface calculated by the two-stream radiative transfer model versus the surface flux in the $0.2-4.0 \mu \mathrm{m}$ spectral range, provided by AERONET. Correlation coefficient $(r=100 \%)$ and slope $(0.998 \pm 0.005)$ of the regression line fitting the data points reveal the very good accordance of AERONET data with the ones retrieved by 5 our model and further more support the appropriateness of our model.

Figures $11 \mathrm{a}, \mathrm{b}$ show the ToA-DRE by all aerosol particles (DRE $\left.{ }_{t, \mathrm{ToA}}\right)$ at solar and IR wavelengths, respectively as a function of $\eta$ values at $0.55 \mu \mathrm{m}$. The sfc-DRE by all aerosol particles $\left(\mathrm{DRE}_{t, \mathrm{sfc}}\right)$ versus $\eta$ is plotted in Fig. 11d, e at solar and IR wavelengths, respectively. Figure $11 \mathrm{c}$, f show the net (solar+IR) DRE at the ToA and surface, 10 respectively. We observe from Fig. $11 \mathrm{a}, \mathrm{d}$ that $\mathrm{DRE} \mathrm{E}_{t, \mathrm{ToA}}$ and $\mathrm{DR} \mathrm{E}_{t, \mathrm{sfc}}$ values at solar wavelengths span the $-(38-11) \mathrm{Wm}^{-2}$ and $-(58-25) \mathrm{Wm}^{-2}$ range, respectively and increase with $\eta$ mainly at the surface. The $\mathrm{AOD}_{t}$ increase for the larger contribution of coarse mode particles (Fig. 7a) as $\eta$ values decrease contribute to these results. Figure 11 also shows that ToA- and sfc-DRE values span within a wide range but, data 15 points relating to a particular dusty-day vary within a rather small range. This last observation in addition to the marked dependence of DRE values on $\eta$, indicate that the high variability of aerosol microphysical properties is mainly responsible for the high variability of the aerosol DRE at the ToA and surface, revealed by Fig. 11. The aerosol DRE at the surface is always smaller than that at the ToA since aerosols not only scat20 ter but also absorb solar radiation. The solar $\mathrm{DRE}_{t, \mathrm{sfc}} / \mathrm{DRE} \mathrm{E}_{t, \mathrm{ToA}}$ ratio that is plotted versus $\eta$ in Fig. 12a, spans the 1.3-3.2 range in accordance with previous studies (e.g. Tafuro et al., 2007; Bergamo et al., 2008a,b; Meloni et al., 2003). Figure 12b shows the atmospheric forcing $\left(\mathrm{AF}_{t}\right)$ versus $\eta$. The $\mathrm{AF}_{t}$ is defined as the difference between ToA and surface aerosol DRE at solar wavelengths. It is and indicator of aerosol effects on atmosphere dynamics: $\mathrm{AF}_{t}$ values lead to a stabilizing effect on the atmospheric stratification. $\mathrm{AF}_{t}$ values span the $8.8-35 \mathrm{~W} \mathrm{~m}^{-2}$ range and are quite dependent on dusty-day and on monitoring time.

Figure $13 \mathrm{a}-\mathrm{c}$ show the $\mathrm{AOD}_{t}$ at $0.55 \mu \mathrm{m}$ and the solar DRE at the ToA and surface versus the solar zenith angle $(\theta)$ in order to investigate the sensitivity on $\theta$ of $A O D_{t}$

\section{Aerosol direct radiative forcing}

M. R. Perrone et al.

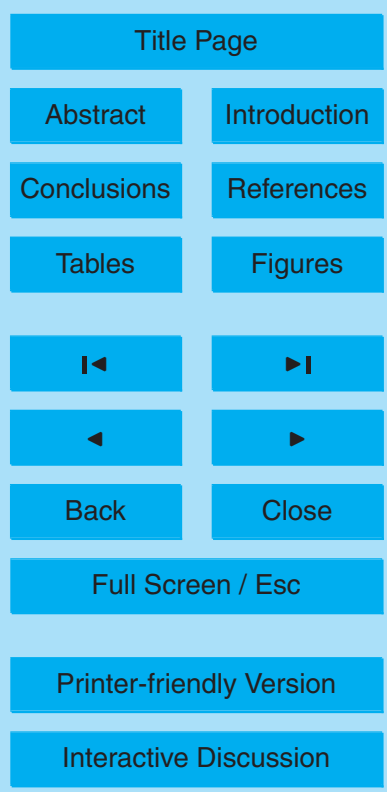


and instantaneous aerosol DRE values. The results reported in this study are based on measurements performed at solar zenith angles spanning the $54-76^{\circ}$ range. The $\mathrm{AOD}_{t}$ on average increases with $\theta$ (Fig. 13a). In addition, we observe that the aerosol DRE has a minimum within the $60-70^{\circ}$ range at the ToA (Fig. 13b). Whereas, the 5 aerosol DRE has a minimum within the $55-65^{\circ}$ range at the surface (Fig. 13c). These results are in satisfactory accordance with the one reported by Meloni et al., 2005. The strong dependence of the upwelling radiation on the particle's dimensions for particles of large radii is responsible for the results of Fig. $13 \mathrm{~b}-\mathrm{c}$. These last results indicate that the solar zenith angle is mainly responsible for the daily variability of instantaneous 10 DRE values at the ToA and surface.

Figure 14a, b shows the aerosol forcing efficiency (AFE) in the solar spectral range versus $\eta$ at the ToA and surface, respectively. The AFE represents the aerosol DRE per unit of $\mathrm{AOD}_{t}$ at $0.55 \mu \mathrm{m}$ and is mainly dependent on aerosol size and composition. ToA- and sfc-AFE values span the - (81-45) $\mathrm{Wm}^{-2}$ and - (156-79) $\mathrm{Wm}^{-2}$ range, re15 spectively. The variability range of both parameters is not significantly affected by $\eta$ and hence, by the contribution of large dust particles. Figure 14c, $d$ shows the AFE as a function of the solar zenith angle, at the ToA and surface, respectively. We observe that AFE values are quite dependent on $\theta$ mainly at the surface. Hence, the high variability of the AFE revealed by Fig. 14 is due to the solar zenith angle and to the vari20 ability of the aerosol microphysical properties during dust intrusion events. It is worth noting that solar-AFEs of this study are significantly larger than the ones reported by Meloni et al. (2003) both at the ToA and surface.

Figure $11 \mathrm{~b}$, e show the ToA- and sfc-DREs at IR wavelengths, respectively and reveal that both parameters on average decrease as $\eta$ values increase, being the IR-DRE mainly due to coarse mode particles. IR-DRE $E_{t, \mathrm{ToA}}$ and IR-DRE $\mathrm{I}_{t, \mathrm{sfc}}$ values vary up to 7 and $19 \mathrm{~W} \mathrm{~m}^{-2}$ at the ToA and surface, respectively. In particular, the IR-DRE $t$, ToA offsets the solar-DRE $E_{t, \text { ToA }}$ from 1 up to $26 \%$. Whereas, the IR-DRE $t$,sfc offsets the solar-DRE $t$,sfc from 5 up to $47 \%$. These last results clearly show the importance of taking into account the IR-DRE during dust intrusion events.

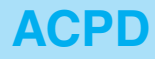

9, 22539-22579, 2009

\section{Aerosol direct radiative forcing}

M. R. Perrone et al.

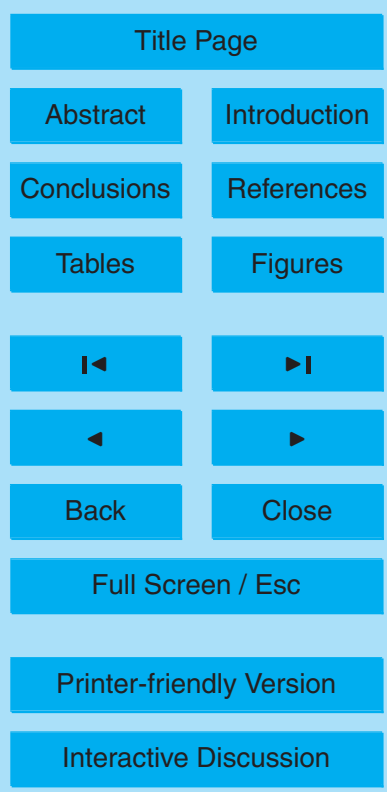




\subsection{Instantaneous DREs by anthropogenic particles on dusty days}

Instantaneous solar-DREs by anthropogenic particles vary from -13 up to $-8 \mathrm{~W} \mathrm{~m}^{-2}$ and from -18 up to $-12 \mathrm{~W} \mathrm{~m}^{-2}$ at the ToA $\left(\mathrm{DRE}_{a, \mathrm{ToA}}\right)$ and surface $\left(\mathrm{DRE}_{a, \mathrm{sfc}}\right)$, respectively. Figure $15 \mathrm{a}, \mathrm{d}$ show the scatterplot of $\mathrm{DRE}_{a, \mathrm{ToA}} / \mathrm{DRE}_{t, \mathrm{ToA}}$ and $\mathrm{DRE}_{a, \mathrm{sfc}} / \mathrm{DRE}_{t, \mathrm{sfc}}$ 5 ratios versus $\eta$, respectively and reveal that the contribution of anthropogenic particles to $\mathrm{DRE}_{t}$ increases linearly with $\eta$ both at the ToA and surface. The ToA-DRE by anthropogenic particles that represents on average $40 \%$ of that by all aerosol particles at $\eta \cong 0.4$, represents $80 \%$ of the $\mathrm{DRE}_{t, \mathrm{ToA}}$ at at $\eta \cong 0.8$. Whereas, 30 and $60 \%$ of the $\mathrm{DRE}_{t, \mathrm{sfc}}$ is due to anthropogenic particles at $\eta \cong 0.4$ and at $\eta \cong 0.8$, respectively. 10 Hence, Fig. 15 clearly shows the significant contribution of anthropogenic particles to the Earth-Atmosphere energy balance during Mediterranean Sahara dust outbreaks. Several studies have revealed that $\eta$ values spanning the $0.3-0.8$ range are on average retrieved by satellite- and ground-based radiometer measurements, during Sahara dust intrusions over the Mediterranean (e.g. Santese et al., 2007, 2008; Meloni et al., 15 2007). Solid lines represent in Fig. 15a, d regression lines fitting the data points. Correlation coefficient $(r)$ and slope $(b)$ also are given in each plot. We believe that the high $r$ values may lead assuming in the solar spectral range that:

$\mathrm{DRE}_{a, \mathrm{ToA}} \cong \eta \times \mathrm{DRE}_{t, \mathrm{ToA}}$

$\mathrm{DRE}_{a, \mathrm{sfc}} \cong 0.7 \times \eta \times \mathrm{DRE}_{t, \mathrm{sfc}}$

20 IR-DREs by anthropogenic particles span the $0.01-0.6 \mathrm{~W} \mathrm{~m}^{-2}$ and the $0.3-$ $1.8 \mathrm{~W} \mathrm{~m}^{-2}$ range at the ToA and surface, respectively. The IR-DRE ${ }_{a \text {,ToA }}$ offsets the solar-DRE ${ }_{a, \text { ToA }}$ from 0.1 up to $4 \%$. Whereas, the IR-DRE ${ }_{a, \text { sfc }}$ offsets the solar-DRE $a$,sfc from 2 up to $11 \%$. Figures $15 \mathrm{~b}$ and $15 \mathrm{e}$ show the scatterplot of the IR-DRE ${ }_{a \text {,ToA }} / \mathrm{IR}_{\mathrm{R}}$ $\mathrm{DRE}_{t, \mathrm{ToA}}$ and IR-DRE $\mathrm{I}_{a, \mathrm{sfc}} / \mathrm{IR}-\mathrm{DRE} \mathrm{E}_{t, \mathrm{sfc}}$ ratio versus $\eta$, respectively: the contribution of 25 anthropogenic particles to IR-DRE ${ }_{t}$ increases linearly with $\eta$ both at the ToA and surface. Solid lines represent regression lines fitting the data points. Hence, we can

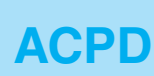

9, 22539-22579, 2009

\section{Aerosol direct radiative forcing}

M. R. Perrone et al.

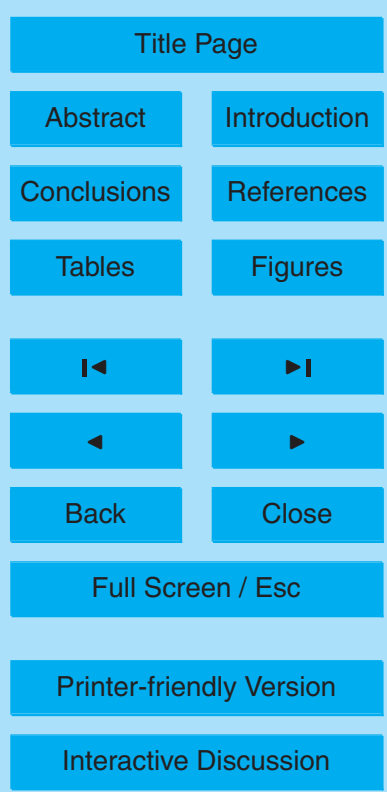


assume in the infrared spectral range that:

$\mathrm{IR}-\mathrm{DRE}_{a, \mathrm{ToA}} \cong 0.2 \times \eta \times \mathrm{IR}^{\mathrm{DRR}} \mathrm{D}_{t, \mathrm{ToA}}$

$\mathrm{IR}-\mathrm{DRE}_{a, \mathrm{sfc}} \cong 0.3 \times \eta \times \mathrm{IR}-\mathrm{DRE}_{t, \mathrm{sfc}}$

Figure $15 \mathrm{c}$, f show net (solar+IR) DRE ${ }_{a} / \mathrm{DRE}_{t}$ ratios versus $\eta$ at the ToA and surface, 5 respectively, which also increase linearly with $\eta$.

To first approximation (valid at aerosol optical thickness sufficiently small that multiple aerosol scattering is a small fraction of aerosol extinction) DREs by natural and anthropogenic particles are linear in the amount of aerosol present (Bates et al., 2006). Thus, in the limit of low aerosol optical depth, for optical depth $\mathrm{AOD}_{a}$ by anthropogenic particles and $\mathrm{AOD}_{n}$ by natural particles the linear assumption

$\mathrm{DRE}_{t}=\mathrm{DRE}_{a}+\mathrm{DRE}_{n}$

is expected to hold, where $\mathrm{DRE}_{n}$ represents the DRE by natural particles. If we assume that the natural aerosol is mainly made by desert dust particles during Sahara dust intrusions in the Mediterranean, the aerosol DRE by dust (natural) particles can be estimated by the following relationships in the solar and IR spectral range, in accordance with Eq. (6):

$\mathrm{DRE}_{n, \mathrm{TOA}} \cong(1-\eta) \times \mathrm{DRE}_{t, \mathrm{ToA}}$

$\mathrm{DRE}_{n, \mathrm{sfc}} \cong(1-0.7 \times \eta) \times \mathrm{DRE}_{t, \mathrm{sfc}}$

$\mathrm{IR}-\mathrm{DRE}_{n, \mathrm{TOA}} \cong(1-0.2 \times \eta) \times \mathrm{IR}-\mathrm{DRE}_{t, \mathrm{ToA}}$

$\mathrm{IR} \mathrm{DRE}_{n, \mathrm{sfc}} \cong(1-0.3 \times \eta) \times \mathrm{IR}^{-\mathrm{DRE}} \mathrm{I}_{t, \mathrm{sfC}}$

We believe that Eqs. (7)-(10) could be used to estimate, to first approximation over the Mediterranean basin, the DRE by dust particles in the solar and IR spectral range. The high $\eta$ values that generally are found over European Countries affected by Sahara dust intrusion events, support the importance of taking into account the DRE by anthropogenic particles to properly estimate the DRE by dust particles over the Mediterranean basin.

Aerosol direct radiative forcing

M. R. Perrone et al.

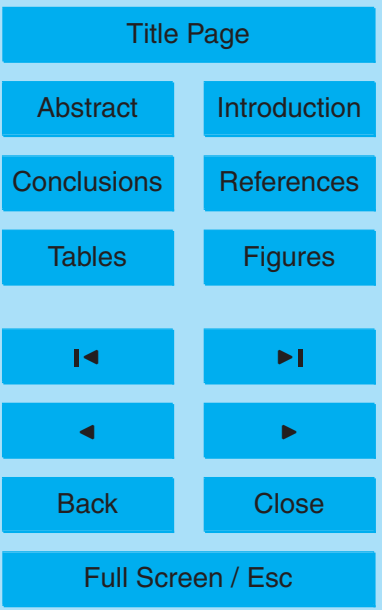

Printer-friendly Version

Interactive Discussion 


\section{Summary and conclusion}

The instantaneous DRE by all and anthropogenic particles is calculated for 9 Sahara dust outbreaks that have affected the Mediterranean basin and south-east Italy from the 2003 to the 2006 year. The clear-sky aerosol DRE is calculated in the solar $(0.3-4 \mu \mathrm{m})$ 5 and infrared $(4-200 \mu \mathrm{m})$ spectral range, at the top of the atmosphere (ToA) and at the Earth's surface (sfc). Observation-based meteorological and aerosol parameters are used to feed the two-stream radiative transfer model. The appropriateness of model input and output is demonstrated by the comparison of simulated surface net-fluxes to broadband net-flux measurements at the surface.

Aerosol optical and microphysical properties are quite dependent on dusty day for the different contribution of anthropogenic particles and probably for the different soil properties of source regions and transport pathways. In fact, instantaneous $n$ and $k$ values at $0.44 \mu \mathrm{m}$ vary within the $1.33-1.55$ and $0.0037-0.014$ range, respectively during the analyzed dust outbreaks and fine mode particles contribute from 34 to $85 \%$ to the total AOD. The variability range of $n$ and $k$ values and the contribution of anthropogenic particles decrease as the AOD increases. In particular, the columnar averaged value \pm 1 SD of $n$ and $k$ is: $\langle n\rangle=1.48 \pm 0.01$ and $\langle k\rangle=0.007 \pm 0.002$ at AODs $>0.45$ at $0.44 \mu \mathrm{m}$, while the contribution of fine mode particles gets smaller than $55 \%$. These last results are in accordance with previous results (Tafuro et al., 2006) and contribute 20 to the characterization of the mean optical properties of the Mediterranean aerosol significantly affected by Sahara dust particles.

The instantaneous solar-DRE by all particles $\left(\mathrm{DRE}_{t}\right)$ spans the $-(38-11) \mathrm{W} \mathrm{m}^{-2}$ and the -(58-25) $\mathrm{W} \mathrm{m}^{-2}$ range at the ToA and surface, respectively as a consequence of the high variability of the aerosol optical and microphysical properties. Solar zenith 25 angles are mainly responsible for the variability of the aerosol DRE observed during a dusty day. The IR-DRE $\mathrm{Itsc}_{t, \mathrm{sc}}$ by all particles offsets the solar-DRE $\mathrm{I}_{t, \mathrm{sfc}}$ from 5 up to $47 \%$. Whereas, the IR-DRE ${ }_{t, \text { ToA }}$ offsets the solar-DRE $t$,ToA from 1 up to $26 \%$. Hence, the importance of taking into account the aerosol IR-DRE during dust intrusion events

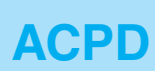

9, 22539-22579, 2009

\section{Aerosol direct radiative forcing}

M. R. Perrone et al.

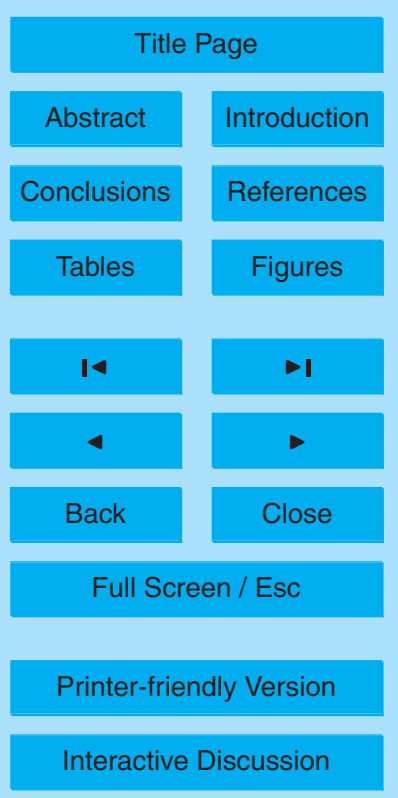


is demonstrated.

The anthropogenic aerosol contribution is associated with a fraction $f$ of the number concentration of fine-mode aerosol $N_{f}(r)$ provided by AERONET, in accordance to Bergamo et al. (2008a). In particular, the AOD at $0.55 \mu \mathrm{m}$ by anthropogenic particles

5 that is quite dependent on dusty day, represents from 27 up to $65 \%$ of the $A O D_{t}$ and allows inferring the significant role of anthropogenic particles in Mediterranean dust events.

To first approximation, DREs by natural and anthropogenic particles are considered linear in the amount of aerosol present. Then, a linear relationship dependent on the 10 fine mode fraction $\eta$ and on the total aerosol DRE is retrieved to calculate the DRE by natural and anthropogenic particles in the solar and infrared spectral range. In particular, if we assume that all natural particles are from the Sahara deserts, the instantaneous solar-DRE by desert particles represents from 20 up to $65 \%$ and from 45 up to $76 \%$ of the instantaneous solar-DRE by all particles at the ToA and surface, 15 respectively during the analyzed dust events. The instantaneous IR-DRE by desert particles represents from 84 up to $93 \%$ and from 76 up to $90 \%$ of the instantaneous IR-DRE by all particles at the ToA and surface, respectively. In conclusion, the paper highlights for the first time, to the best of our knowledge, the significant role of anthropogenic particles (mainly in the solar spectral range) during dust intrusions events in the Mediterranean basin, in order to get a better estimated of the DRE by desert dust particles both at the ToA and surface and in the solar and IR spectral range. The significant role of the IR-DRE by desert dust particles is also highlighted.

Aerosol optical and microphysical properties retrieved from sun/sky radiometer measurements performed at Lecce (a peninsular site in south-east Italy) during selected dust outbreaks are used in this study. Nevertheless, we believe that paper's results can be representative of Mediterranean sites not highly affected by local pollution, in accordance to Bergamo et al. (2008a). Hence, they contribute to the characterization of aerosol- and in particular, of dust-particle-DREs on the energy-balance of the Mediterranean: one of the most responsive regions to climate changes.

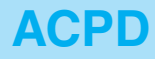

9, 22539-22579, 2009

\section{Aerosol direct radiative forcing}

M. R. Perrone et al.

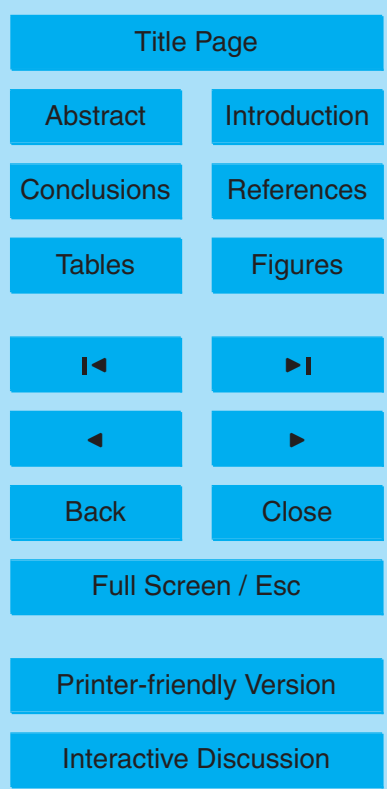


Acknowledgements. This work is supported by Ministero dell' Istruzione dell'Università e della Ricerca of Italy, (Programma di Ricerca di Interesse Nazionale 2006. Prot. 2006027825), by the European Project EARLINET-ASOS (2006 -2011, contract $n$. 025991), and by Progetto FISR AEROCLOUDS. The authors kindly acknowledge S. Kinne for providing the two-stream 5 radiative transfer model and for the constructive discussions.

\section{References}

Balkanski, Y., Schulz, M., Claquin, T., and Guibert, S.: Reevaluation of Mineral aerosol radiative forcings suggests a better agreement with satellite and AERONET data, Atmos. Chem. Phys., 7, 81-95, 2007, http://www.atmos-chem-phys.net/7/81/2007/.

Bates, T. S., Anderson, T. L., Baynard, T., Bond, T., Boucher, O., Carmichael, G., Clarke, A., Erlick, C., Guo, H., Horowitz, L., Howell, S., Kulkarni, S., Maring, H., McComiskey, A., Middlebrook, A., Noone, K., O'Dowd, C. D., Ogren, J., Penner, J., Quinn, P. K., Ravishankara, A. R., Savoie, D. L., Schwartz, S. E., Shinozuka, Y., Tang, Y., Weber, R. J., and Wu, Y.: Aerosol direct radiative effects over the northwest Atlantic, northwest Pacific, and North Indian Oceans: estimates based on in-situ chemical and optical measurements and chemical transport modeling, Atmos. Chem. Phys., 6, 1657-1732, 2006, http://www.atmos-chem-phys.net/6/1657/2006/.

Bergamo, A., Tafuro, A. M., Kinne, S., De Tomasi, F., and Perrone, M. R.: Monthly-averaged anthropogenic aerosol direct radiative forcing over the Mediterranean based on AERONET aerosol properties, Atmos. Chem. Phys., 8, 6995-7014, 2008, http://www.atmos-chem-phys.net/8/6995/2008/.

Bergamo, A., De Tomasi, F., and Perrone, M. R.: Direct radiative effects by anthropogenic particles at a polluted site: Rome (Italy), II Nuovo Cimento, 31C, 513-526, doi:10.1393/ncc/i2009-10320-1, 2008b.

Dentener, F., Kinne, S., Bond, T., Boucher, O., Cofala, J., Generoso, S., Ginoux, P., Gong, S., Hoelzemann, J. J., Ito, A., Marelli, L., Penner, J. E., Putaud, J.-P., Textor, C., Schulz, M., van der Werf, G. R., and Wilson, J.: Emissions of primary aerosol and precursor gases in the years 2000 and 1750 prescribed data-sets for AeroCom, Atmos. Chem. Phys., 6, 4321-

\section{Aerosol direct radiative forcing}

M. R. Perrone et al.

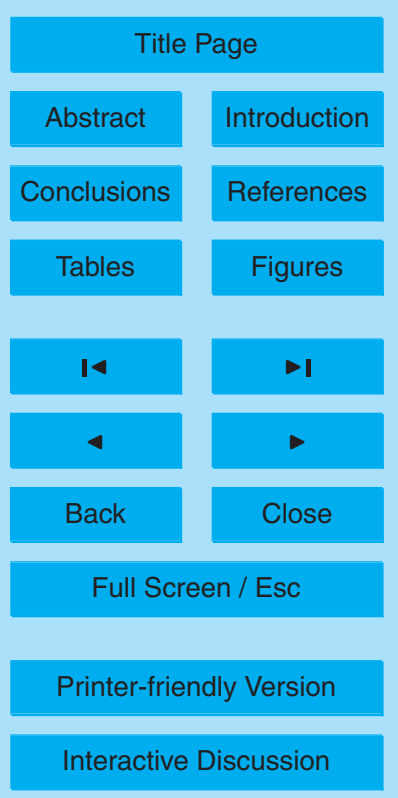

Interactive Discussion 
4344, 2006,

http://www.atmos-chem-phys.net/6/4321/2006/.

De Tomasi, F., Blanco, A., and Perrone, M. R.: Raman lidar monitoring of extinction and backscattering of Africa dust layers and dust characterization, Appl. Optics, 42, 1699-1709, 52003

De Tomasi, F., Tafuro, A. M., and Perrone, M. R: Height and seasonal dependence of aerosol optical properties over south-east Italy, J. Geophys. Res., 111, D10203, doi:10.1029/2005JD006779, 2006.

di Sarra, A., Di lorio, T., Cacciani, M., Fiocco, G., and Fuá, D.: Saharan dust profiles measured by lidar at Lampedusa, J. Geophys. Res., 106, 10335-10347, 2001.

Haywood, J., Francis, P., Osborne, S., Glew, M., Loeb, N., Highwood, E., Tanré, D., Myhre, D., Formenti, P., and Hirst, E.: Radiative properties and direct radiative effect of Saharan dust measured by the C-130 aircraft during SHADE: 1. Solar spectrum, J. Geophys. Res., 108(D18), 8577, doi:10.1029/2002JD002687, 2003.

15 Hamonou, E., Chazette, P., Balis, D., Dulac, F., Scheider, X., Galani, E., Ancellet, G., and Papayannos, A.: Characterization of the vertical structure of Saharan dust export to the Mediterranean basin, J. Geophys. Res., 104, 22257-22270, 1999.

Holben, B. N., Eck, T. F., Slutsker, I., Tanré, D., Buis, J. P., Setzer, A., Vermote, E., Reagan, J. A., Kaufman, Y. J., Nakajima, T., Lavenu, F., Jankowiak, I., and Smirnov, A.: AERONET - a federate instrument network and data archive for aerosol characterization, Remote Sens. Environ., 66, 1-16, 1998.

King, M. D., Kaufman, Y. J., Menzel, W. P., Tanré, D.: Remote sensing of cloud, aerosol, and water vapor properties from the Moderate Resolution Imaging Spectrometer (MODIS), IEEE T. Geosci. Remote, 30, 1-27, 1992.

Matthias, V., Balis, D., Boesenberg, J., Eixmann, R., larlori, M., Komguem, L., Mattis, I., Papayannis, A., Pappalardo, G., Perrone, M. R., and Wang, X.: Vertical aerosol distribution over Europe: statistical analysis of Raman lidar data from 10 European Aerosol Research Lidar Network (EARLINET) stations, J. Geophys. Res., 109, D18201, doi:10.1029/2004JD004638, 2004.

30 Meloni, D., di Sarra, A., Di lorio, T., and Fiocco, G., Junkermann, W., and Pace, G.: Tropospheric aerosols in the Mediterranean: 2. Radiative effects through model simulations and measurements, J. Geophys. Res., 108(D10), 4317, doi:10.1029/2002JD002807, 2003.

Meloni, D., di Sarra, A., Di Iorio, T., and Fiocco, G.: Influence of the vertical profile of Saharan

\section{Aerosol direct radiative forcing}

M. R. Perrone et al.

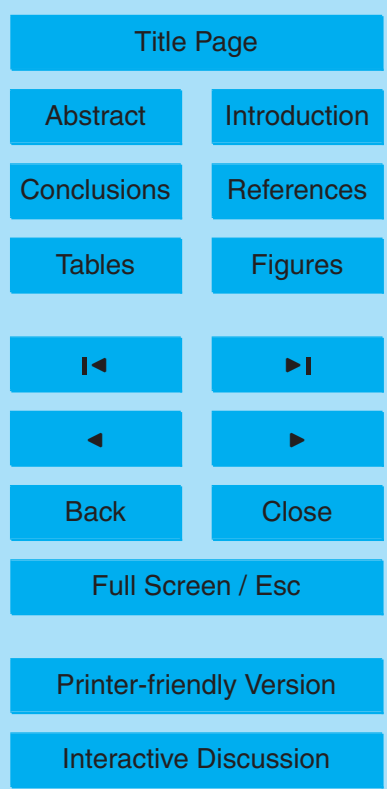


dust on the visible direct radiative forcing, J. Quant. Spectrosc. Ra., 93, 347-413, 2005.

Meloni , D., di Sarra, A., Biavati, G., DeLuisi, J. J., Monteleone, F., Pace, G., Piacentino, S., and Sferlazzo, D. M.: Seasonal behavior of Saharan dust events at the Mediterranean island of Lampedusa in the period 1999-2005, Atmos. Environ., 41, 3041-3056, 2007.

5 Meador, W. E and Weaver, W. R.: Two-stream approximation to radiative transfer in planetary atmospheres: a unified description of existing methods and new improvement, J. Atmos. Sci., 37, 630-643, 1980.

Pavese, G., De Tomasi, F., Calvello, M., Esposito, F., and, Perrone, M. R.: Detection of Sahara dust intrusions during mixed advection patterns over south-east Italy: a case study, Atmos.

10 Res., 92, 489-504, doi:10.1016/j.atmosres.2009.02.003, 2009.

Reddy, M. S., Boucher, O., Balanski, Y., and Schulz, M.: Aerosol optical depths and direct radiative perturbations by species and source type, Geophys. Res. Lett., 32, L12803, doi:10.1029/2004GL021743, 2005.

Santese, M., De Tomasi, F., and Perrone, M. R.: Moderate Resolution Imaging Spectroradiome15 ter (MODIS) and Aerosol Robotic Network (AERONET) retrievals during dust outbreaks over the Mediterranean, J. Geophys. Res., 112, D18201, doi:10.1029/2007JD008482, 2007.

Santese, M., De Tomasi, F., and Perrone, M. R.: Advection patterns and aerosol optical and microphysical properties by AERONET over south-east Italy in the central Mediterranean, Atmos. Chem. Phys., 8, 1881-1896, 2008,

20 http://www.atmos-chem-phys.net/8/1881/2008/.

Schulz, M., Textor, C., Kinne, S., Balkanski, Y., Bauer, S., Berntsen, T., Berglen, T., Boucher, O., Dentener, F., Guibert, S., Isaksen, I. S. A., Iversen, T., Koch, D., Kirkevåg, A., Liu, X., Montanaro, V., Myhre, G., Penner, J. E., Pitari, G., Reddy, S., Seland, Ø., Stier, P., and Takemura, T.: Radiative forcing by aerosols as derived from the AeroCom present-day and pre-industrial simulations, Atmos. Chem. Phys., 6, 5225-5246, 2006, http://www.atmos-chem-phys.net/6/5225/2006/.

Sokolik, I. N., Winker, D., Bergametti, G., Gillette, D., Carmichael, G., Kaufman, Y., Gomes, L., Schuetz, L., and Penner, J.: Introduction to special section on mineral dust: outstanding problems in quantifying the radiative impact of mineral dust, J. Geophys. Res., 106, 1801518027, 2001.

Stier, P., Seinfeld, J. H., Kinne, S., and Boucher, O.: Aerosol absorption and radiative forcing, Atmos. Chem. Phys., 7, 5237-5261, 2007, http://www.atmos-chem-phys.net/7/5237/2007/.

\section{Aerosol direct radiative forcing}

M. R. Perrone et al.

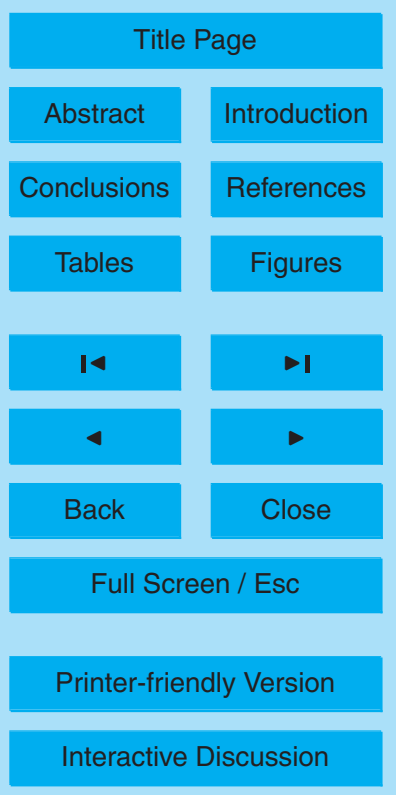

\section{1}


Tafuro, A. M., Banaba, F., De Tomasi, F., Perrone, M. R., and Gobbi, G. P.: Saharan dust particle properties over the central Mediterranean, Atmos. Res., 81, 67-93, 2006.

Tafuro, A. M., Kinne, S., De Tomasi, F., and Perrone, M. R.: Annual cycle of aerosol direct radiative effect over southeast Italy and sensitivity studies, J. Geophys. Res., 112, D20202, doi:10.1029/2006JD008265, 2007.

Tafuro, A. M., De Tomasi, F., and Perrone, M. R.: Remote Sensing of Aerosols by Sunphotometers and Lidar Techniques, chap. 14, in: Advanced Environmental Monitoring, edited by: Kim, Y. J. and Platt, U., Springer, ISBN 978-1-4020-6363-3, XXII, 179-189, 2008.

Tegen, I.: Modeling the mineral dust aerosol cycle in the climate system, Quaternary Sci. Rev., 22, 1821-1834, 2003.

\section{ACPD}

9, 22539-22579, 2009

\section{Aerosol direct radiative forcing}

M. R. Perrone et al.

Title Page

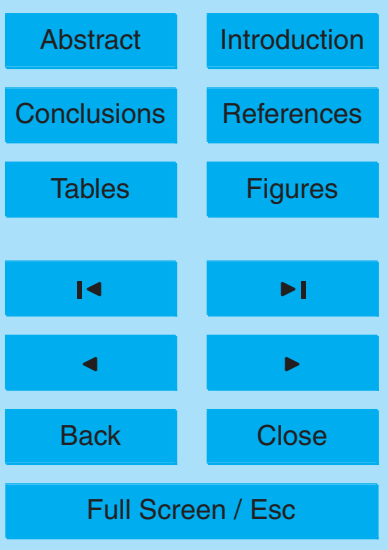

Printer-friendly Version

Interactive Discussion 
Table 1. Instantaneous values of AOD, real $(n)$ and imaginary $(k)$ refractive index at $0.44 \mu \mathrm{m}$ retrieved by AERONET sun/sky radiometer measurements, Angstrom coefficient $(\AA)$ computed from AOD values at $0.44 \mu \mathrm{m}$ and $0.87 \mu \mathrm{m}$, and surface albedo values $(\alpha)$ calculated from AERONET products.

\begin{tabular}{|c|c|c|c|c|c|c|}
\hline $\begin{array}{l}\text { dd month yyyy } \\
\text { hh:mm }\end{array}$ & $\begin{array}{c}\text { AOD } \\
(0.44 \mu \mathrm{m})\end{array}$ & $\begin{array}{c}\AA \\
(0.44 / 0.87)\end{array}$ & $\begin{array}{c}n \\
(0.44 \mu \mathrm{m})\end{array}$ & $\begin{array}{c}k \\
k \\
(0.44 \mu \mathrm{m})\end{array}$ & $\begin{array}{c}\alpha \\
(0.3-0.7 \mu \mathrm{m})\end{array}$ & $\begin{array}{c}\alpha \\
(0.7-5 \mu \mathrm{m})\end{array}$ \\
\hline $\begin{array}{c}17 \text { Jul } 2003 \\
04: 59\end{array}$ & 0.71 & 0.23 & 1.47 & 0.0044 & 0.11 & 0.37 \\
\hline $\begin{array}{c}24 \text { Jul } 2003 \\
06: 58\end{array}$ & 0.44 & 0.63 & 1.42 & 0.0055 & 0.097 & 0.31 \\
\hline $\begin{array}{c}24 \text { Jul } 2003 \\
14: 52\end{array}$ & 0.38 & 0.65 & 1.41 & 0.0056 & 0.098 & 0.31 \\
\hline $\begin{array}{c}24 \text { Jul } 2003 \\
15: 24\end{array}$ & 0.41 & 0.69 & 1.42 & 0.0070 & 0.10 & 0.32 \\
\hline $\begin{array}{c}24 \text { Jul } 2003 \\
16: 26\end{array}$ & 0.41 & 0.66 & 1.44 & 0.0079 & 0.11 & 0.38 \\
\hline $\begin{array}{c}08 \text { Jul } 2004 \\
14: 59\end{array}$ & 0.34 & 0.70 & 1.47 & 0.0059 & 0.097 & 0.31 \\
\hline $\begin{array}{c}08 \text { Jul } 2004 \\
15: 29\end{array}$ & 0.33 & 0.68 & 1.44 & 0.0059 & 0.10 & 0.32 \\
\hline $\begin{array}{c}08 \mathrm{Jul} 2004 \\
16: 25\end{array}$ & 0.32 & 0.68 & 1.49 & 0.0050 & 0.11 & 0.36 \\
\hline $\begin{array}{l}05 \mathrm{Jul} 2005 \\
14: 58\end{array}$ & 0.25 & 1.38 & 1.52 & 0.0096 & 0.10 & 0.31 \\
\hline $\begin{array}{c}05 \text { Jul } 2005 \\
15: 30\end{array}$ & 0.27 & 1.35 & 1.50 & 0.014 & 0.10 & 0.32 \\
\hline $\begin{array}{c}05 \text { Jul } 2005 \\
16: 26\end{array}$ & 0.31 & 1.51 & 1.52 & 0.011 & 0.11 & 0.36 \\
\hline $\begin{array}{c}05 \text { Jul } 2005 \\
16: 54\end{array}$ & 0.32 & 1.50 & 1.53 & 0.011 & 0.11 & 0.38 \\
\hline $\begin{array}{c}06 \text { Jul } 2005 \\
14: 59\end{array}$ & 0.28 & 1.06 & 1.50 & 0.0054 & 0.10 & 0.31 \\
\hline $\begin{array}{c}06 \text { Jul } 2005 \\
15: 30\end{array}$ & 0.32 & 1.09 & 1.55 & 0.0037 & 0.10 & 0.32 \\
\hline $\begin{array}{c}06 \text { Jul } 2005 \\
16: 26\end{array}$ & 0.35 & 1.25 & 1.46 & 0.0039 & 0.11 & 0.36 \\
\hline $\begin{array}{c}06 \text { Jul } 2005 \\
16: 53\end{array}$ & 0.34 & 1.36 & 1.33 & 0.0054 & 0.11 & 0.38 \\
\hline $\begin{array}{c}18 \text { Jul } 2005 \\
15: 00\end{array}$ & 0.32 & 0.87 & 1.44 & 0.0095 & 0.10 & 0.31 \\
\hline $\begin{array}{c}18 \text { Jul } 2005 \\
15: 27\end{array}$ & 0.42 & 0.84 & 1.48 & 0.011 & 0.10 & 0.32 \\
\hline $\begin{array}{l}18 \text { Jul } 2005 \\
16: 49\end{array}$ & 0.40 & 0.90 & 1.52 & 0.0093 & 0.11 & 0.38 \\
\hline $\begin{array}{l}19 \text { Jun } 2006 \\
15: 30\end{array}$ & 0.49 & 0.34 & 1.49 & 0.0074 & 0.09 & 0.31 \\
\hline $\begin{array}{l}19 \text { Jun } 2006 \\
16: 26\end{array}$ & 0.52 & 0.36 & 1.47 & 0.0066 & 0.10 & 0.34 \\
\hline $\begin{array}{c}19 \text { Jun } 2006 \\
16: 53\end{array}$ & 0.53 & 0.38 & 1.47 & 0.0083 & 0.10 & 0.37 \\
\hline $\begin{array}{l}22 \text { Jun } 2006 \\
15: 31\end{array}$ & 0.39 & 0.46 & 1.50 & 0.0097 & 0.093 & 0.31 \\
\hline $\begin{array}{l}22 \text { Jun } 2006 \\
16: 27\end{array}$ & 0.42 & 0.52 & 1.43 & 0.0082 & 0.10 & 0.34 \\
\hline $\begin{array}{l}26 \text { Jun } 2006 \\
15: 00\end{array}$ & 0.32 & 0.76 & 1.44 & 0.0075 & 0.097 & 0.31 \\
\hline $\begin{array}{c}26 \text { Jun } 2006 \\
15: 31\end{array}$ & 0.34 & 0.61 & 1.45 & 0.0075 & 0.10 & 0.32 \\
\hline
\end{tabular}

\section{ACPD}

9, 22539-22579, 2009

\section{Aerosol direct radiative forcing}

M. R. Perrone et al.

Title Page

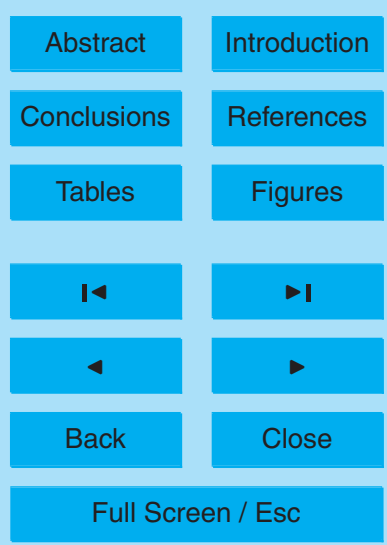

Printer-friendly Version

Interactive Discussion 


\section{ACPD}

9, 22539-22579, 2009

\section{Aerosol direct radiative forcing}

Table 2. Instantaneous surface net-flux $\left(F_{\text {sfc }}\right)$ in the solar $(0.3-4 \mu \mathrm{m})$ and IR $(4-200 \mu \mathrm{m})$ spectral range, DRE by all $\left(\mathrm{DRE}_{t}\right)$ and anthropogenic $\left(\mathrm{DRE}_{a}\right)$ particles at the top of the atmosphere (ToA) and surface (sfc), and in the solar $(0.3-4 \mu \mathrm{m})$ and IR $(4-200 \mu \mathrm{m})$ spectral range, and $\mathrm{AOD}$ at $0.55 \mu \mathrm{m}$ by all $\left(\mathrm{AOD}_{t}\right)$ and anthropogenic $\left(\mathrm{AOD}_{a}\right)$ particles for 22 July 2006 at different day hours.

\begin{tabular}{lcccc}
\hline Parameter & \multicolumn{2}{c}{$(0.3-4) \mu \mathrm{m}$} & \multicolumn{2}{c}{$(4-200) \mu \mathrm{m}$} \\
\hline Time $(\mathrm{UTC})$ & $15: 31$ & $16: 27$ & $15: 31$ & $16: 27$ \\
$\mathrm{~F}_{\text {sfc }}\left(\mathrm{W} \mathrm{m}^{-2}\right)$ & 301 & 165 & -55 & -53 \\
$\mathrm{DRE}_{t, \text { ToA }}\left(\mathrm{W} \mathrm{m}^{-2}\right)$ & -20 & -25 & 1.7 & 1.8 \\
$\mathrm{DRE}_{t, \mathrm{sfc}}\left(\mathrm{W} \mathrm{m}^{-2}\right)$ & -53 & -45 & 9.1 & 10.0 \\
$\mathrm{DRE}_{a, \mathrm{ToA}}\left(\mathrm{W} \mathrm{m}^{-2}\right)$ & -10 & -11 & 0.04 & 0.04 \\
$\left.\mathrm{DRE}_{a, \text { sfc }}(\mathrm{W} \mathrm{m})^{-2}\right)$ & -16 & -16 & 1.0 & 1.4 \\
$\mathrm{AOD}_{t}(0.55 \mu \mathrm{m})$ & 0.34 & 0.37 & & \\
$\mathrm{AOD}_{a}(0.55 \mu \mathrm{m})$ & 0.13 & 0.14 & & \\
\hline
\end{tabular}

M. R. Perrone et al.

Title Page

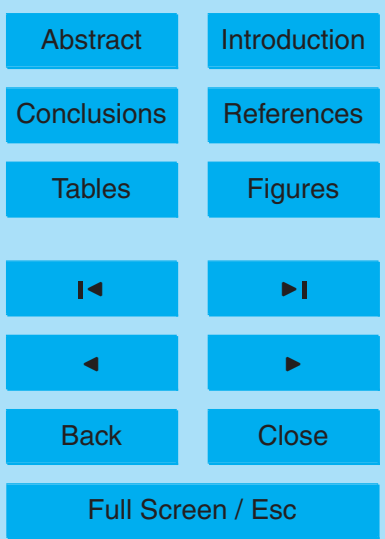

Printer-friendly Version

Interactive Discussion 


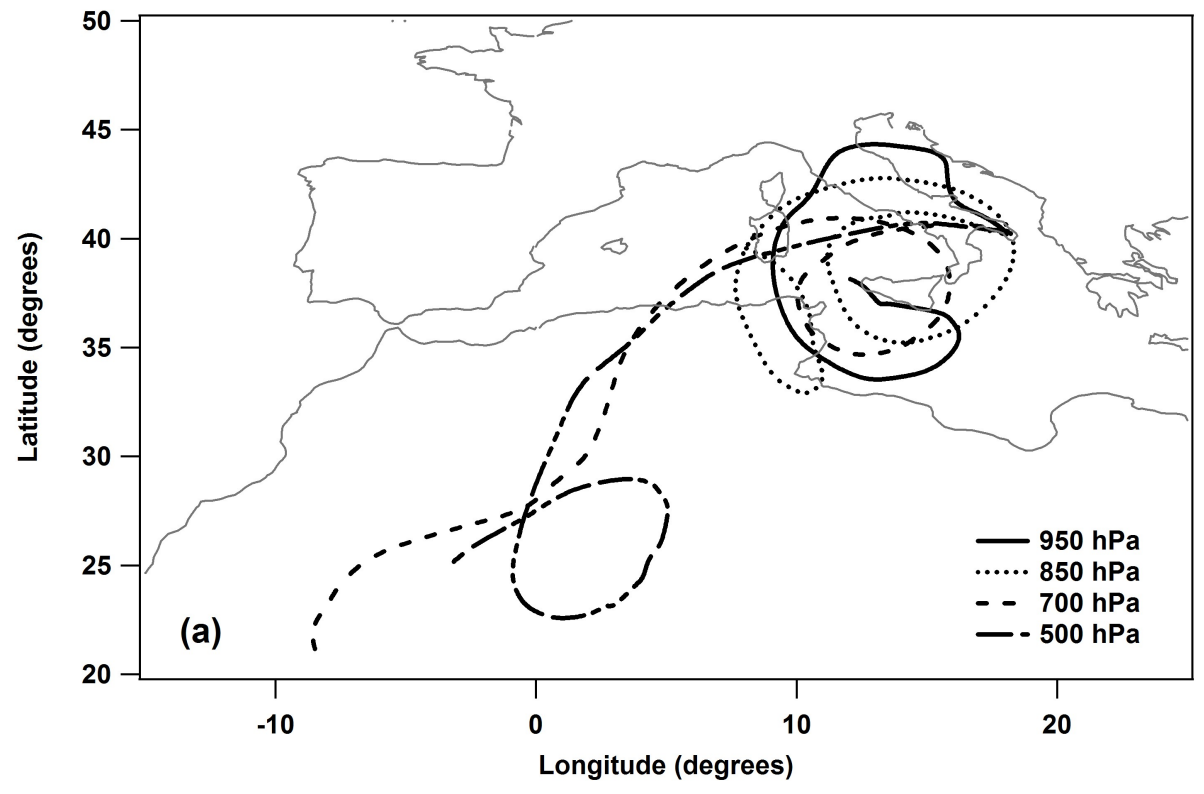

\section{ACPD}

9, 22539-22579, 2009

\section{Aerosol direct radiative forcing}

M. R. Perrone et al.
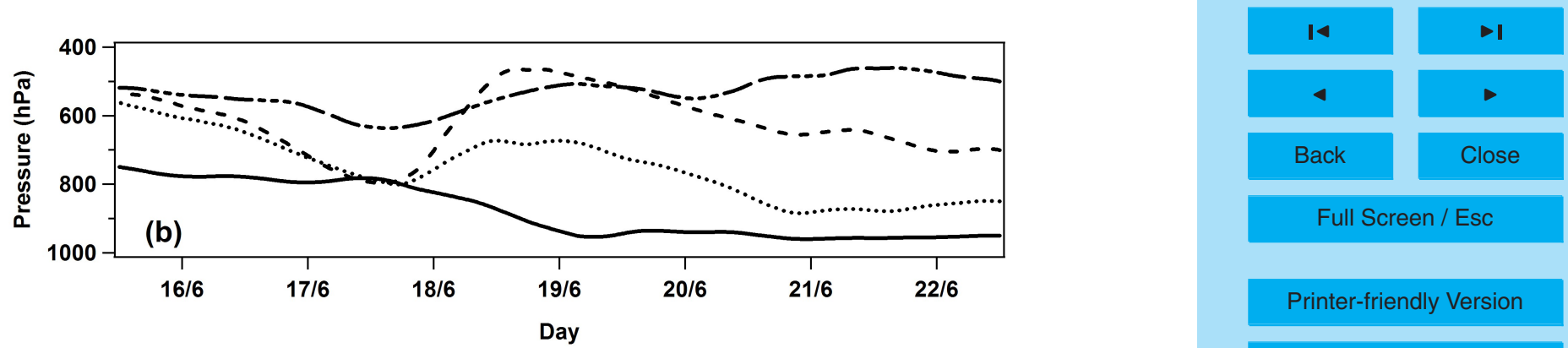

Printer-friendly Version

Fig. 1. (a) Pathways of the 7-day analytical back trajectories at $950,850,700$, and $500 \mathrm{hPa}$ that reach Lecce on 22 June at 12:00 UTC. (b) Altitude of each back trajectory as a function of time. 


\section{ACPD}

9, 22539-22579, 2009

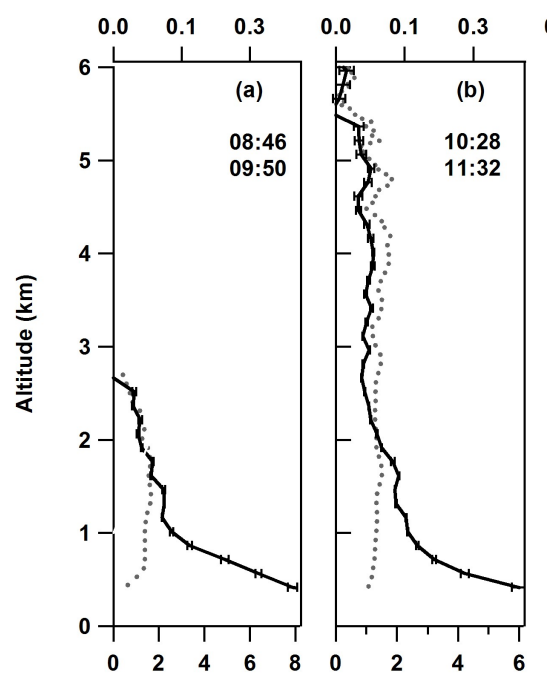

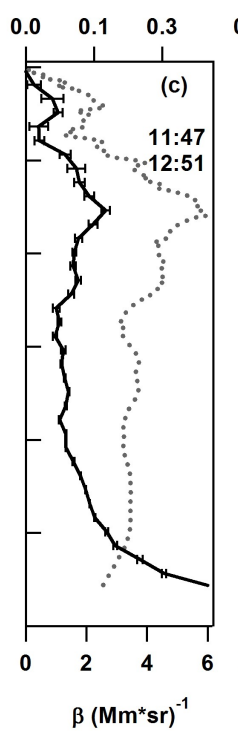

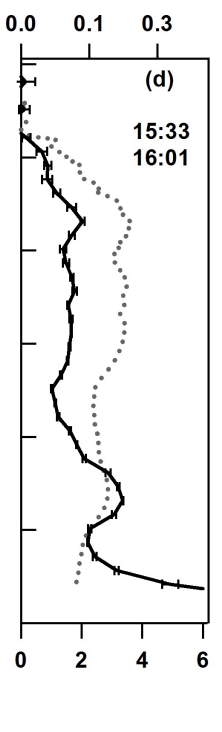

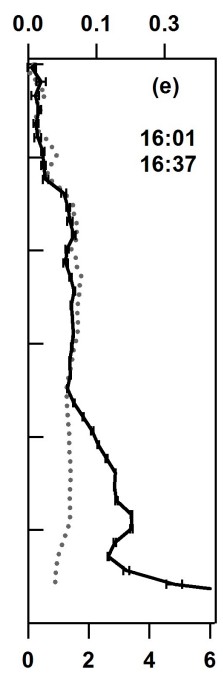

Fig. 2. Aerosol backscatter coefficient profiles (solid lines) from lidar measurements performed on 22 June 2006 at different day hours (UTC). Grey dotted lines represent vertical profiles of the depolarization ratio.

\section{Aerosol direct radiative forcing}

M. R. Perrone et al.
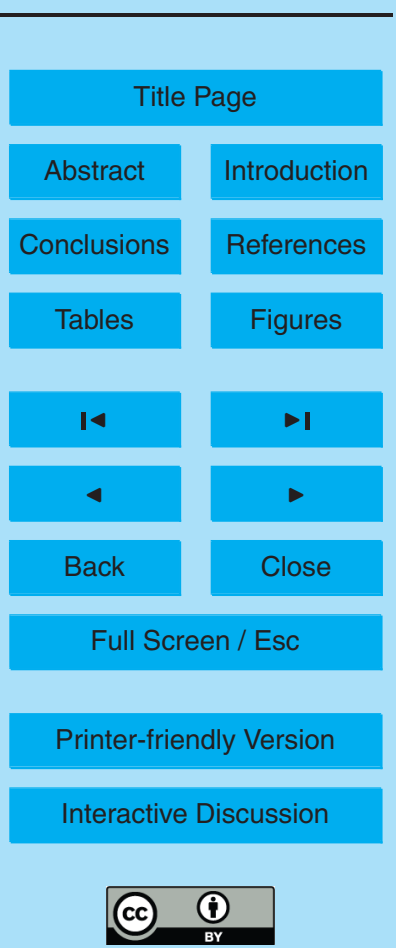


\section{ACPD}

9, 22539-22579, 2009

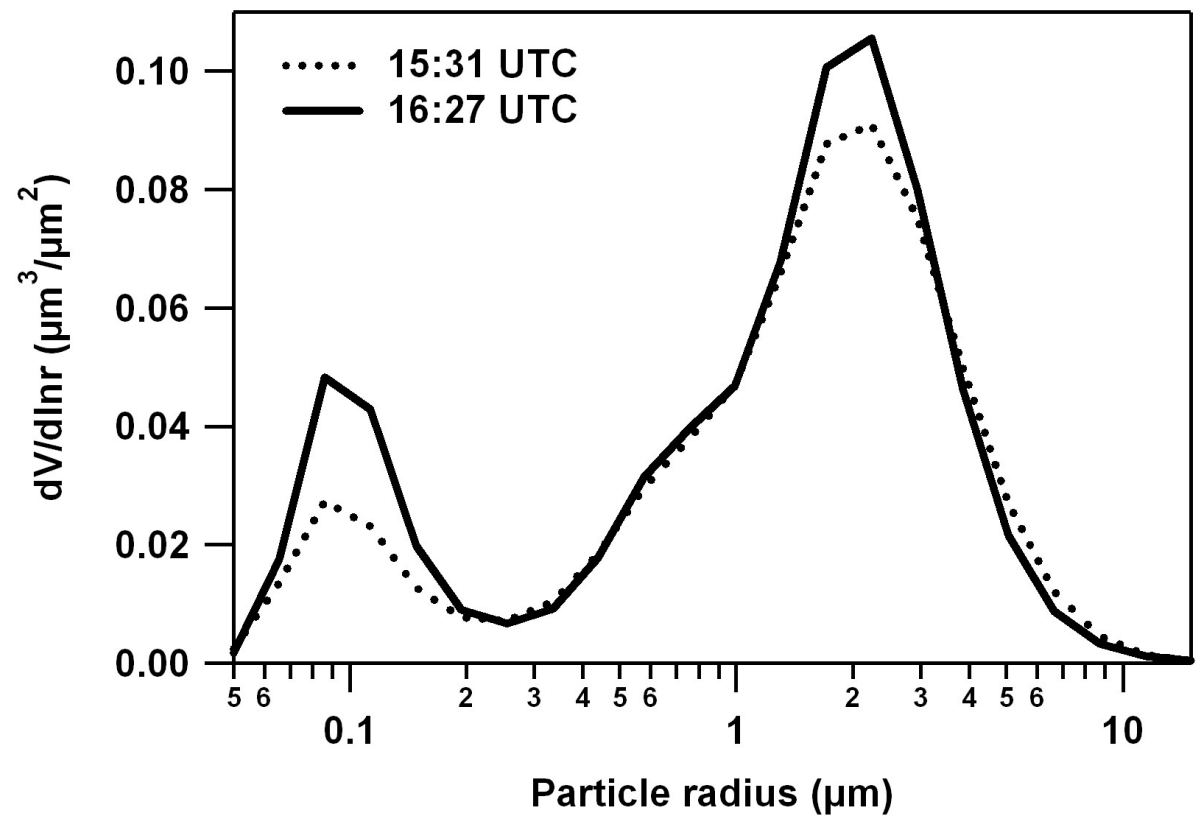

\section{Aerosol direct radiative forcing}

M. R. Perrone et al.

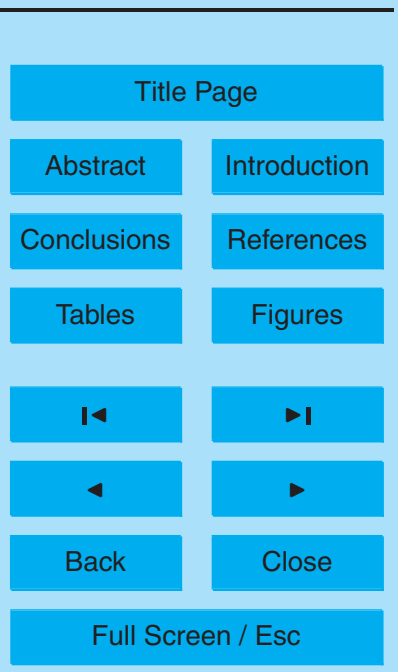

Fig. 3. Columnar volume size distributions from AERONET sun/sky photometer measurements performed on 22 June 2006 at 15:31 UTC (dotted line) and at 16:27 UTC (solid line).

Printer-friendly Version

Interactive Discussion

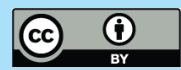




\section{ACPD}

9, 22539-22579, 2009

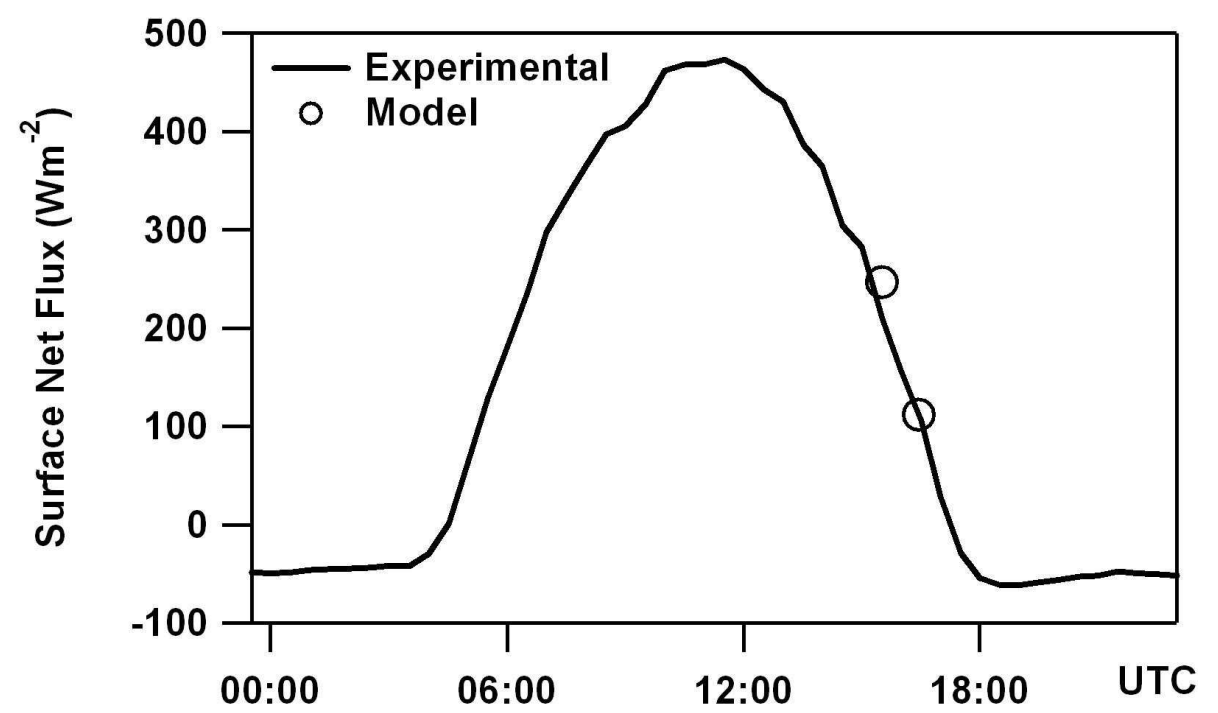

\section{Aerosol direct radiative forcing}

M. R. Perrone et al.

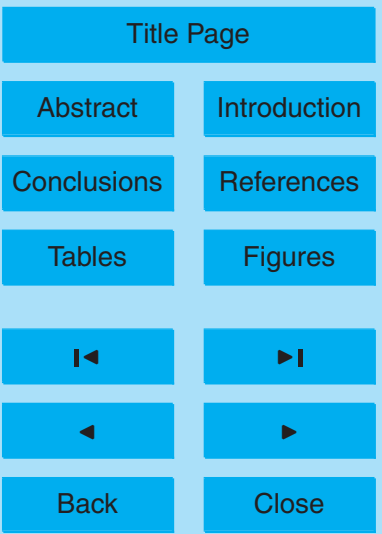

Full Screen / Esc

Fig. 4. Broadband $(0.3-30 \mu \mathrm{m})$ net-flux measurements at the surface (solid line) by a net radiation transducer. Open dots represent instantaneous simulated surface net-fluxes.

Printer-friendly Version

Interactive Discussion

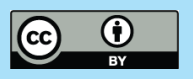




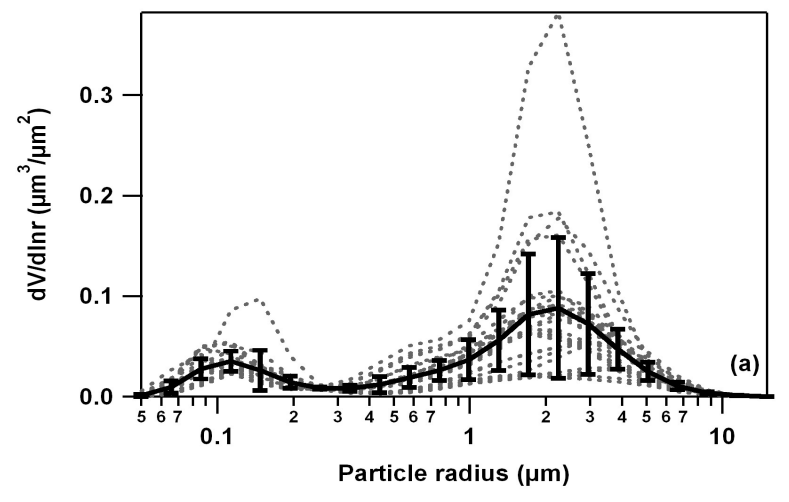

\section{ACPD}

9, 22539-22579, 2009

\section{Aerosol direct radiative forcing}

M. R. Perrone et al.

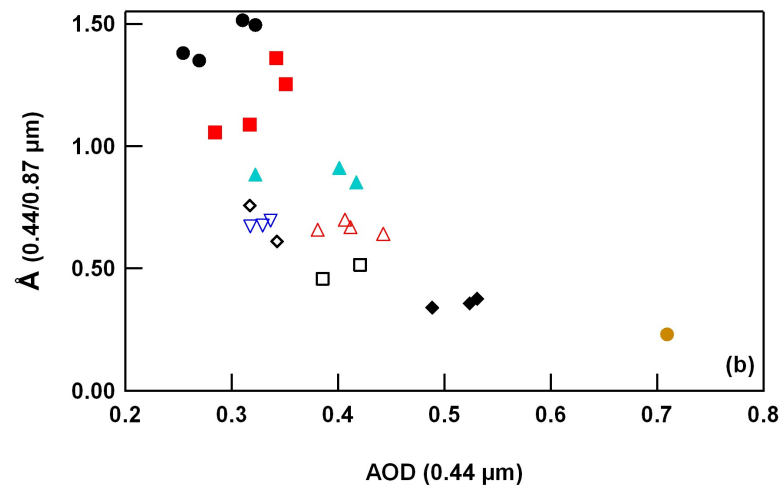

Title Page

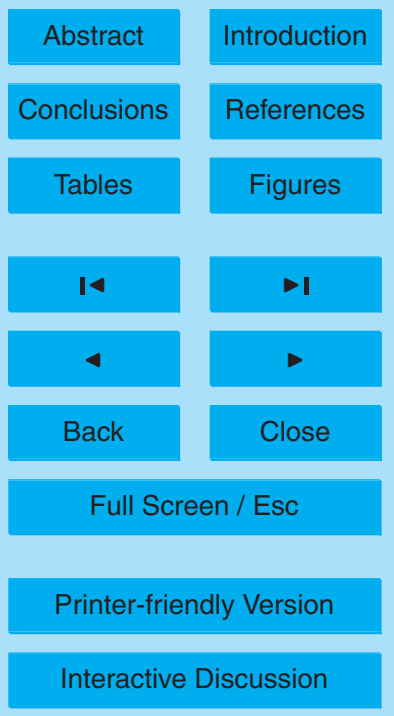

Fig. 5. (a) Instantaneous columnar volume size distributions (dotted grey lines) of the selected dusty days. The black line represents the mean columnar volume size distribution. Vertical bars represent \pm 1 standard deviation from the average value (b) Instantaneous Angstrom coefficient values computed from AODs at $0.44 \mu \mathrm{m}$ and $0.87 \mu \mathrm{m}$ versus the AOD at $0.44 \mu \mathrm{m}$. Different symbols are used to characterize different dusty-days: 17 July $2003(0)$; 24 July $2003(\triangle)$;

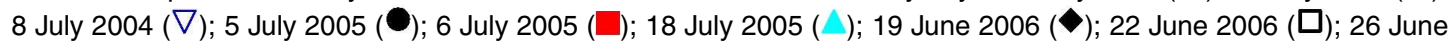
$2006(\mathbf{0})$. 


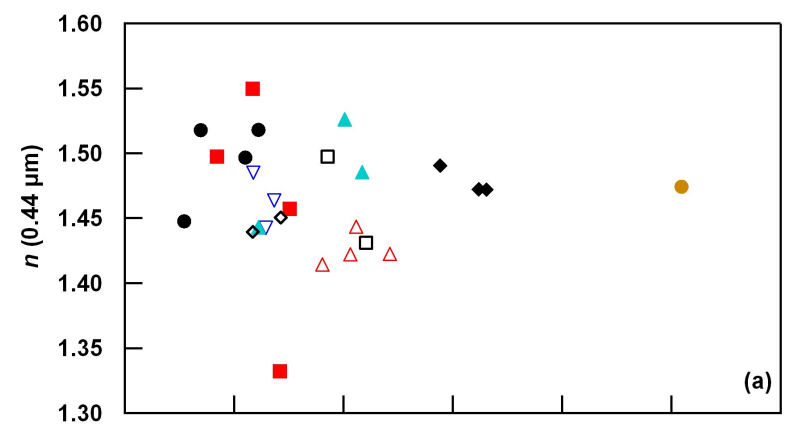

\section{ACPD}

9, 22539-22579, 2009

\section{Aerosol direct radiative forcing}

M. R. Perrone et al.
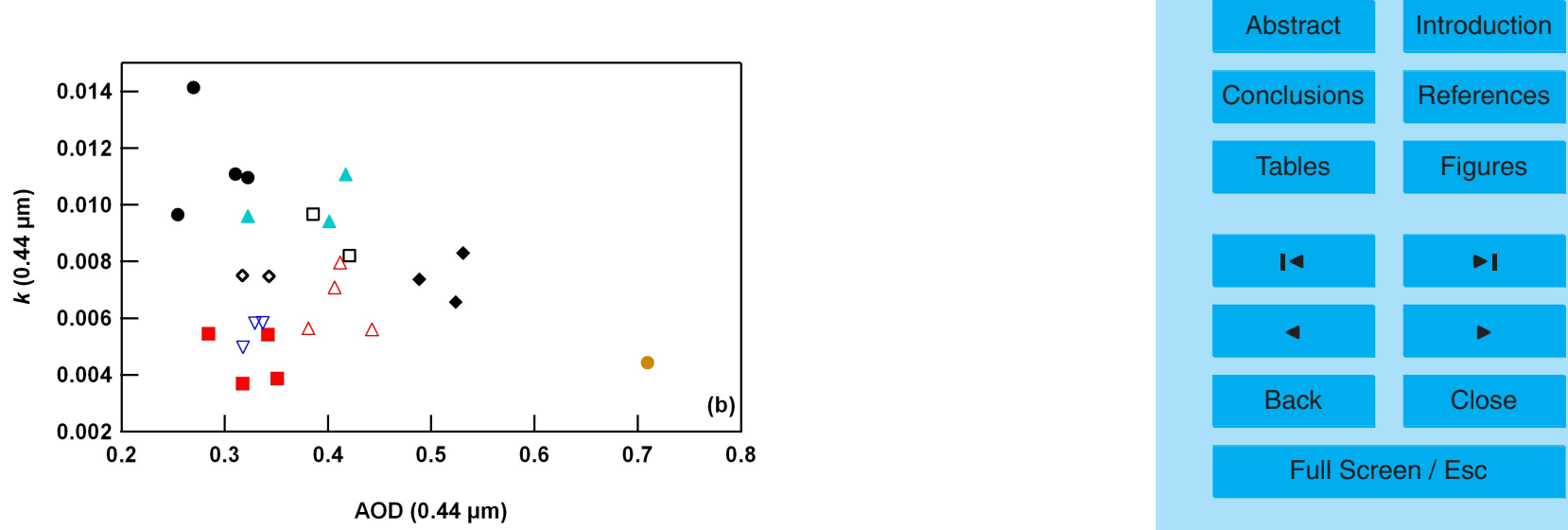

Full Screen / Esc

Fig. 6. Instantaneous values at $0.44 \mu \mathrm{m}$ of (a) $n$ and (b) $k$ versus the AOD by all particles.

Printer-friendly Version 17 July $2003(\odot) ; 24$ July $2003(\triangle)$; 8 July $2004(\nabla)$; 5 July $2005(\bullet) ; 6$ July $2005(\square) ; 18$ July $2005(\triangle)$; 19 June $2006(\diamond)$; 22 June $2006(\square) ; 26$ June $2006(\diamond)$. 


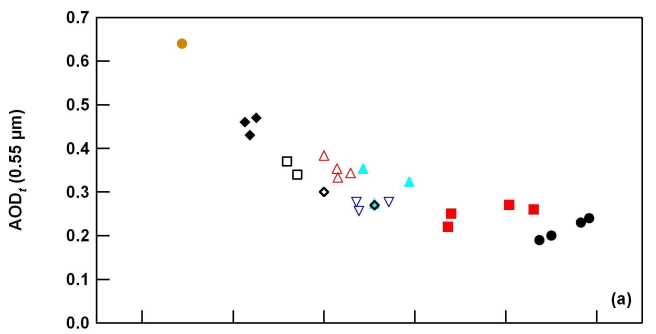

\section{ACPD}

9, 22539-22579, 2009

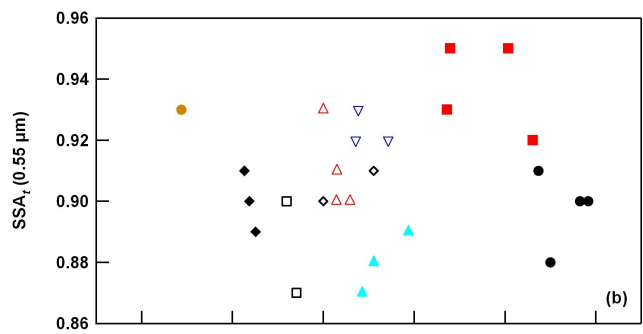

\section{Aerosol direct radiative forcing}

M. R. Perrone et al.
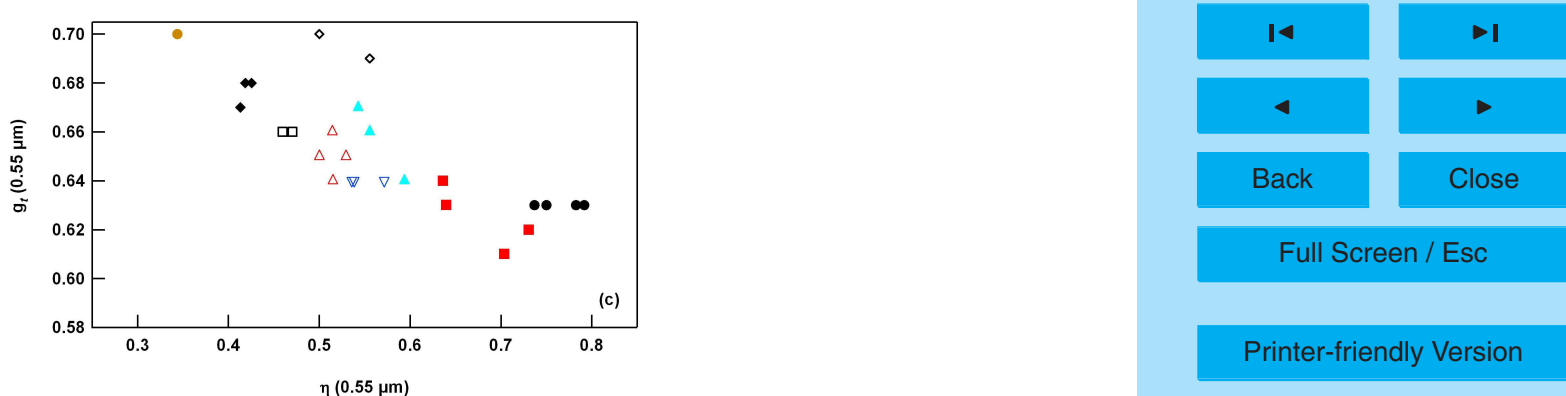

Printer-friendly Version

Fig. 7. Simulated values at $0.55 \mu \mathrm{m}$ of (a) AOD, (b) SSA, and $g$ by all aerosol particles as a function of $\eta$ at $0.55 \mu \mathrm{m}$. Different symbols are used to characterize different dusty-days: 17 July 2003 ( ); 24 July $2003(\triangle)$; 8 July $2004(\nabla)$;

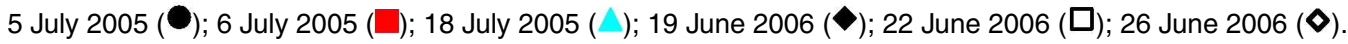




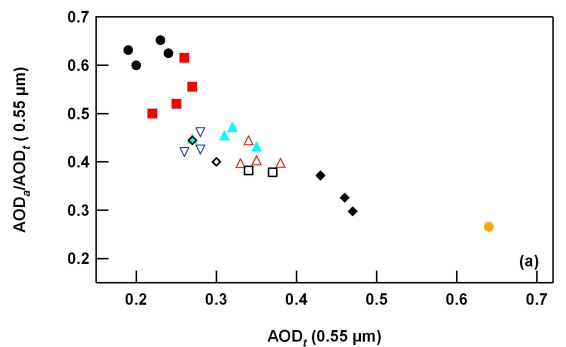

\section{ACPD}

9, 22539-22579, 2009
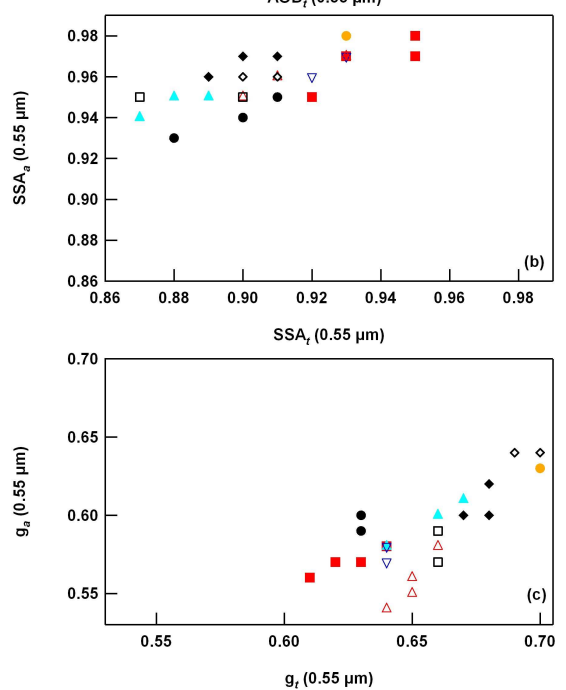

\section{Aerosol direct radiative forcing}

M. R. Perrone et al.

Title Page

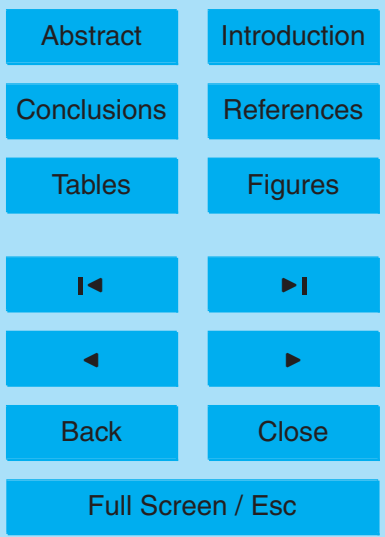

Fig. 8. (a) Ratio by the anthropogenic particle $A O D\left(A O D_{a}\right)$ to the $A O D$ by all particles $\left(A O D_{t}\right)$ versus the $A O D_{t}$. (b) SSA by anthropogenic particles $\left(\mathrm{SSA}_{a}\right)$ versus the one by all particles $\left(\mathrm{SSA}_{t}\right)$. (c) Asymmetry parameter by anthropogenic particles $\left(g_{a}\right)$ versus the one by all particles $\left(g_{t}\right)$. Different symbols are used to characterize different

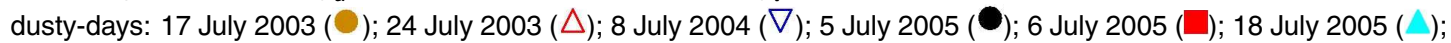
19 June $2006(\diamond) ; 22$ June $2006(\square) ; 26$ June $2006(\diamond)$. 


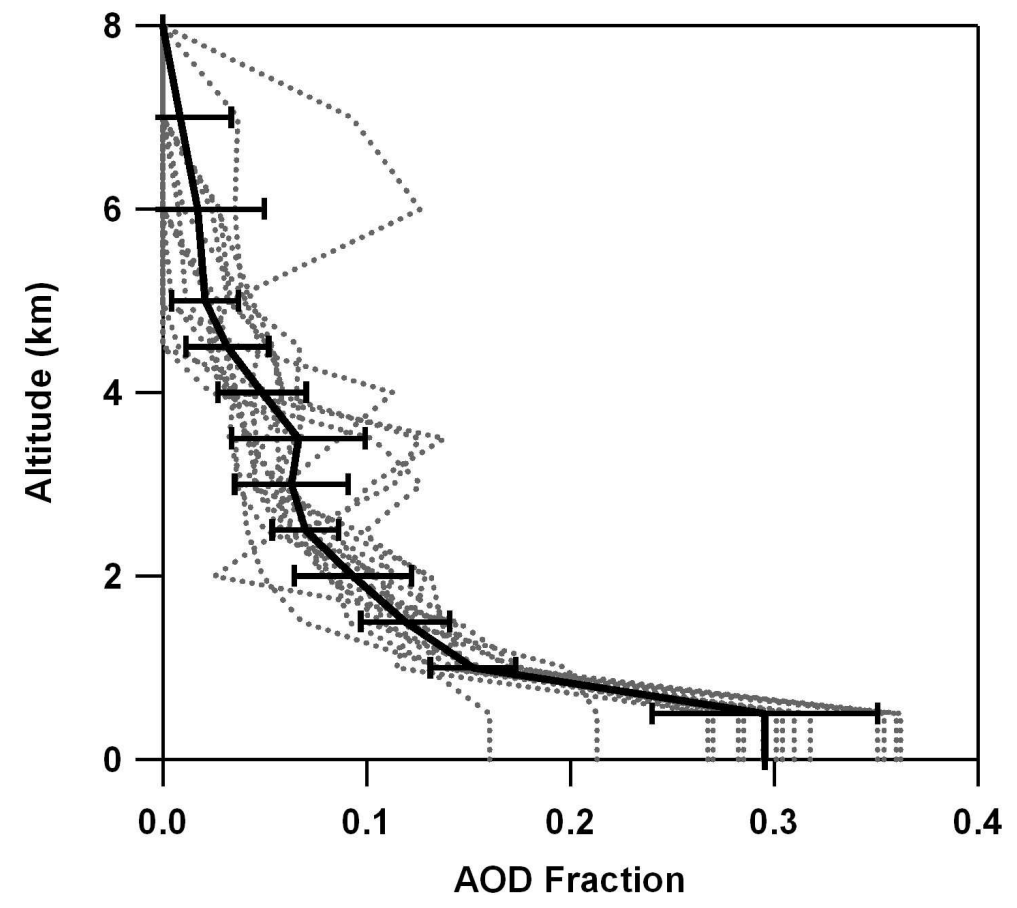

Fig. 9. Instantaneous dusty-day AOD fractions (grey dotted lines) as a function of altitude. The solid line represents the mean vertical profile of the AOD fraction. Horizontal error bars represent \pm 1 standard deviation from the average value.

\section{9, 22539-22579, 2009}

\section{Aerosol direct radiative forcing}

M. R. Perrone et al.

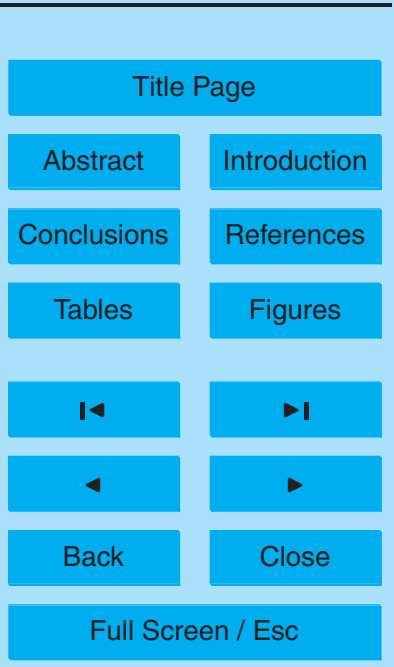

Printer-friendly Version

Interactive Discussion 


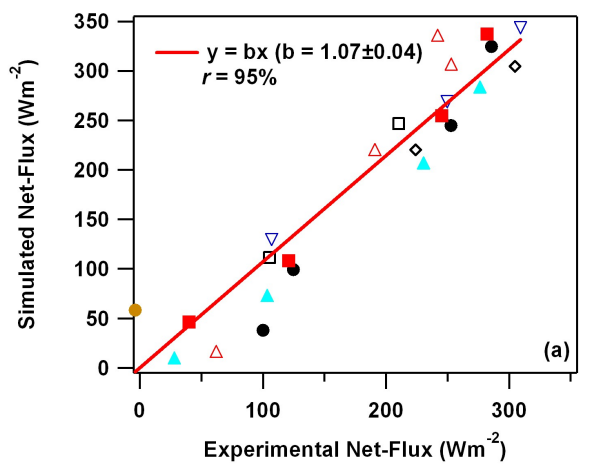

\section{9, 22539-22579, 2009}

\section{Aerosol direct radiative forcing}

M. R. Perrone et al.

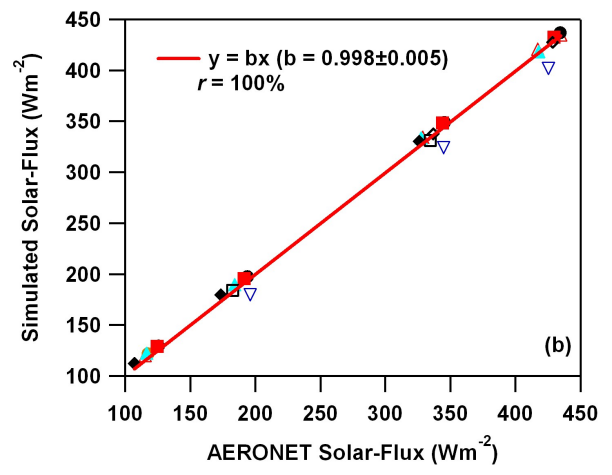

Title Page

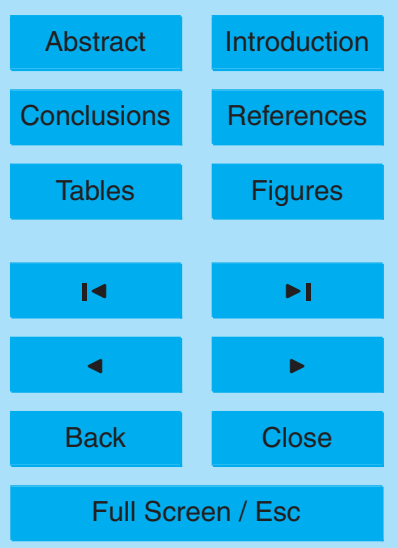

Fig. 10. (a) Simulated versus experimental net-flux values at the surface. (b) Simulated solarflux versus AERONET solar-flux values at the surface. The solid line in each plot represents the regression line fitting the data points. Different symbols are used to characterize different

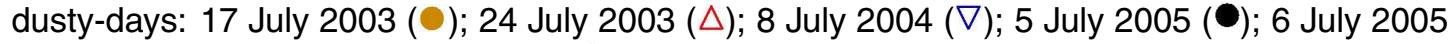
$(\square) ; 18$ July 2005 ( $\triangle$ ); 19 June $2006(\diamond) ; 22$ June $2006(\square) ; 26$ June $2006(\diamond)$.

Printer-friendly Version

Interactive Discussion 

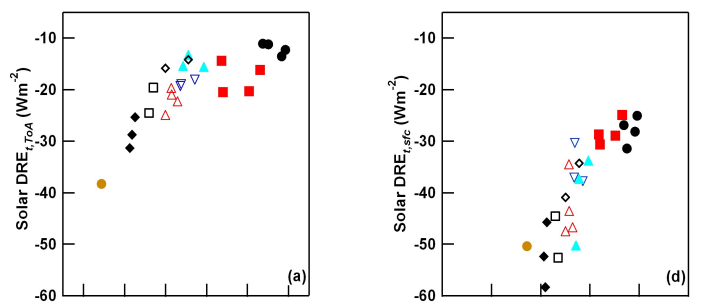

\section{ACPD}

9, 22539-22579, 2009
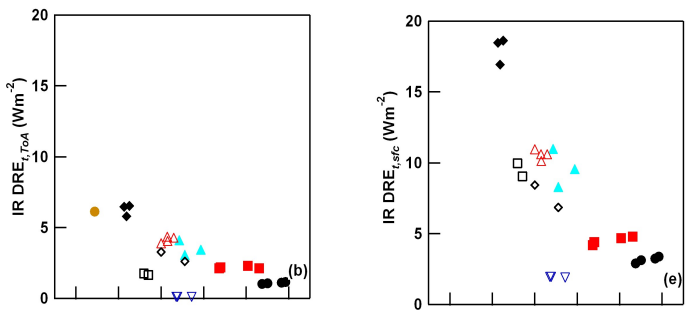

\section{Aerosol direct radiative forcing}

M. R. Perrone et al.
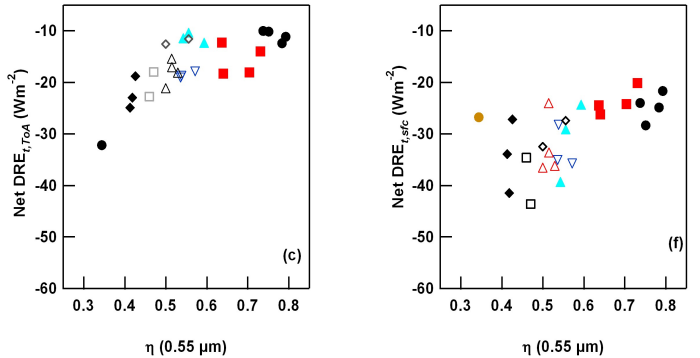

Title Page

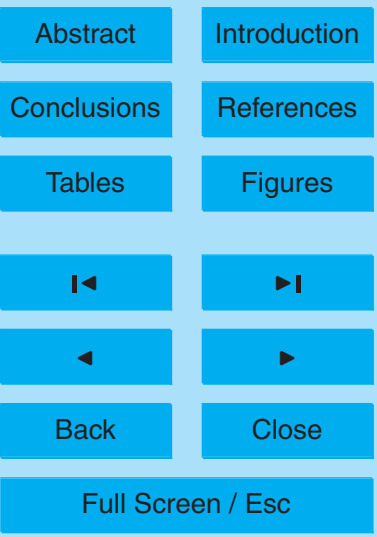

Fig. 11. ToA-DRE by all particles in the (a) solar, (b) $I R$, and (c) solar+IR spectral range as a function of the fine mode fraction $\eta$ at $0.55 \mu \mathrm{m}$. sfc-DRE by all particles in the (d) solar, (e) IR, and (f) solar+IR spectral range as a function $\eta$. Different symbols are used to characterize different dusty-days: 17 July 2003 (О); 24 July 2003 ( $\triangle$ ); 8 July 2004

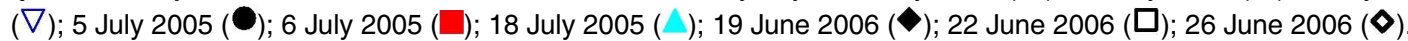




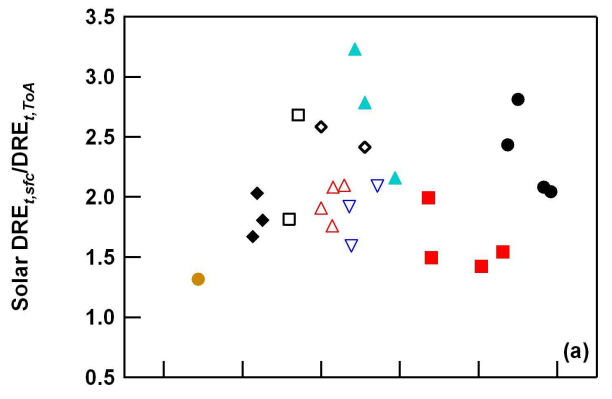

ACPD

9, 22539-22579, 2009

\section{Aerosol direct radiative forcing}

M. R. Perrone et al.

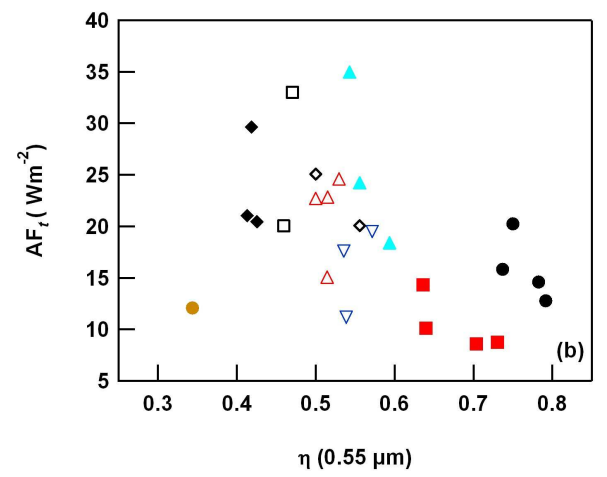

Title Page

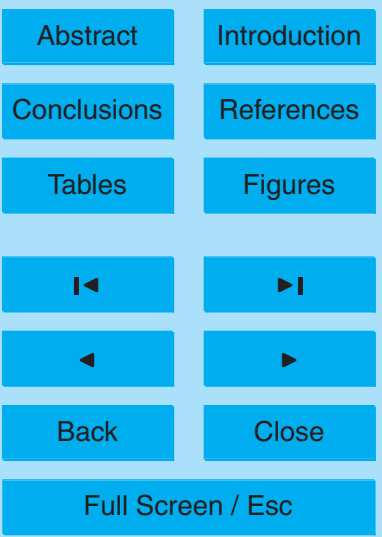

Fig. 12. (a) Ratio of the sfc-DRE to the ToA-DRE by all particles in the solar spectral range as a function of the fine mode fraction $\eta$ at $0.55 \mu \mathrm{m}$. (b) Atmospheric forcing by all particles in the solar spectral range versus $\eta$ at $0.55 \mu \mathrm{m}$. Different symbols are used to characterize different

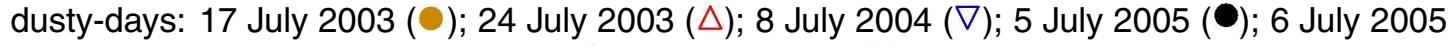

Printer-friendly Version $(\square) ; 18$ July $2005(\triangle)$; 19 June $2006(\diamond) ; 22$ June $2006(\square) ; 26$ June $2006(\diamond)$.

Interactive Discussion 


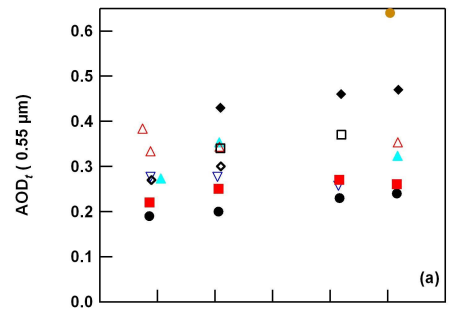

\section{ACPD}

9, 22539-22579, 2009

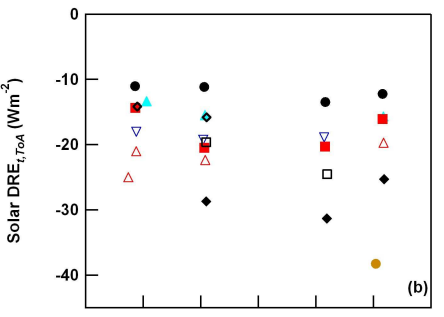

\section{Aerosol direct radiative forcing}

\section{R. Perrone et al.}

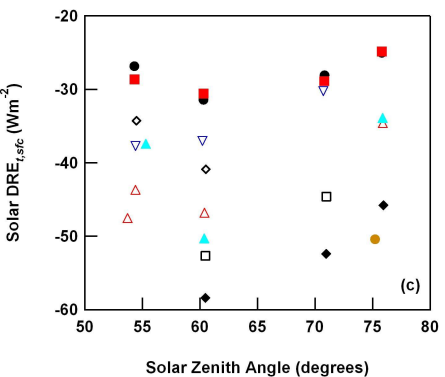

Title Page

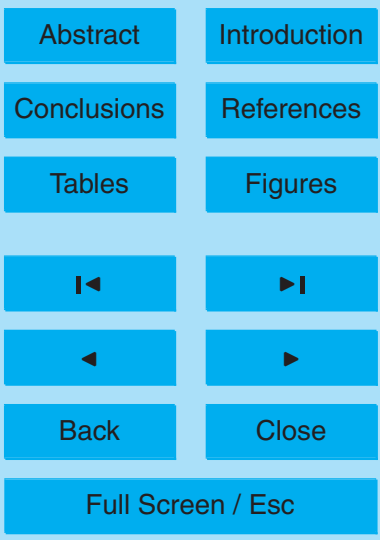

Printer-friendly Version

Fig. 13. (a) $A O D$ at $0.55 \mu \mathrm{m}$, (b) solar ToA-DRE and (c) solar sfc-DRE by all aerosol particles as a function of the solar zenith angle. Different symbols are used to characterize different dusty-days: 17 July 2003 (๑); 24 July $2003(\triangle)$; 8 July 2004 ( $\nabla)$; 5 July $2005(\bullet) ; 6$ July 2005 $(\square) ; 18$ July $2005(\triangle)$; 19 June $2006(\diamond) ; 22$ June $2006(\square) ; 26$ June $2006(\diamond)$.

Interactive Discussion 

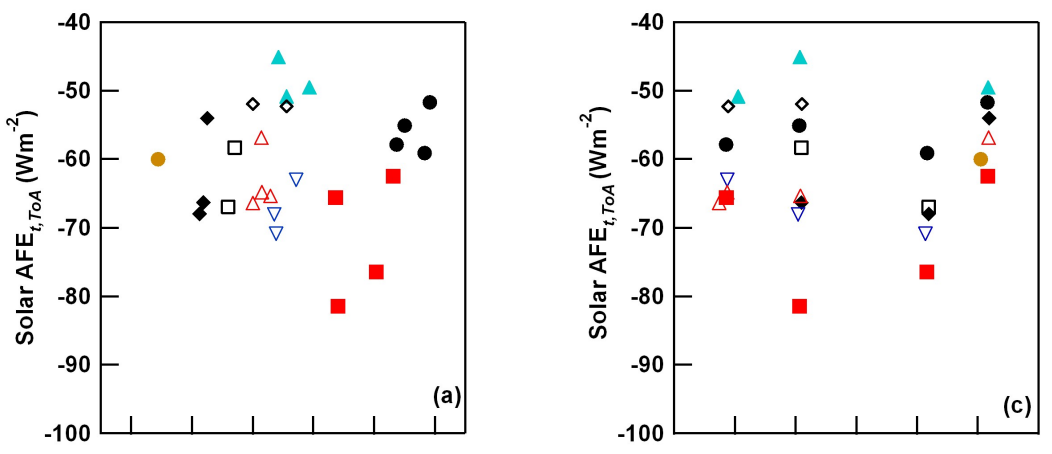

ACPD

9, 22539-22579, 2009

\section{Aerosol direct radiative forcing}

\section{R. Perrone et al.}
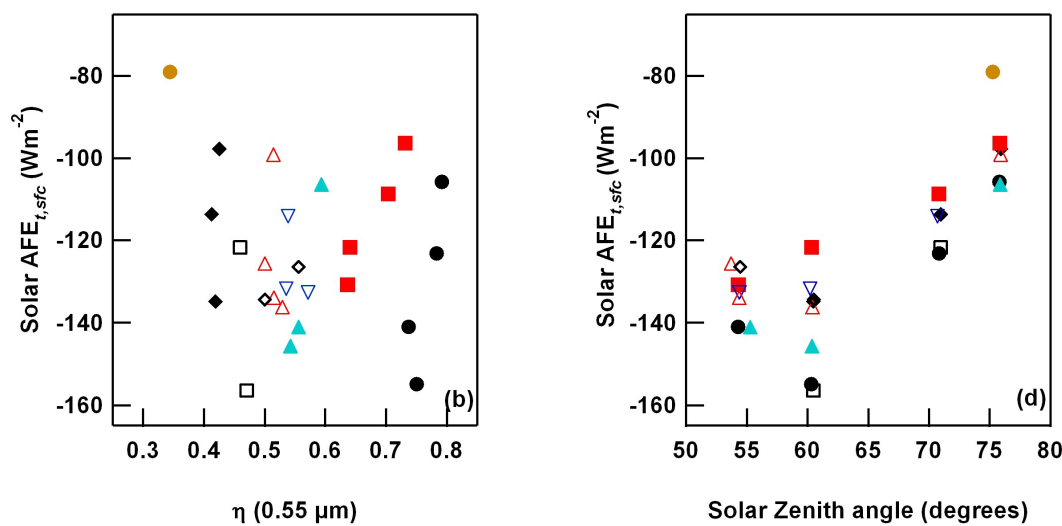

Title Page

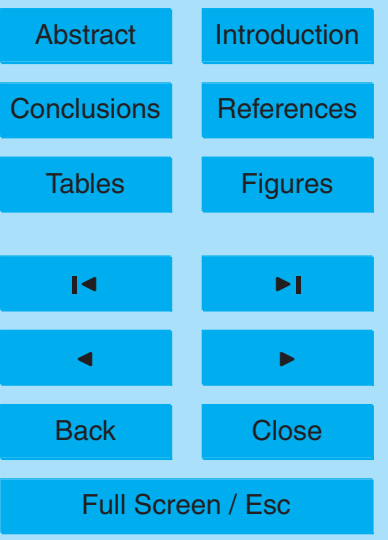

Fig. 14. AFE in the solar spectra range by all aerosol particles versus $\eta$ (a) at the ToA and (b) surface and as a function of the solar zenith angle (c) at the ToA and (d) surface. Different symbols are used to characterize different dusty-days: 17 July $2003(\odot) ; 24$ July $2003(\triangle)$; 8 July $2004(\nabla) ; 5$ July $2005(\bullet) ; 6$ July $2005(\square) ; 18$ July 2005 (\); 19 June $2006(\diamond) ; 22$ June 2006 (口); 26 June $2006(\diamond)$. 

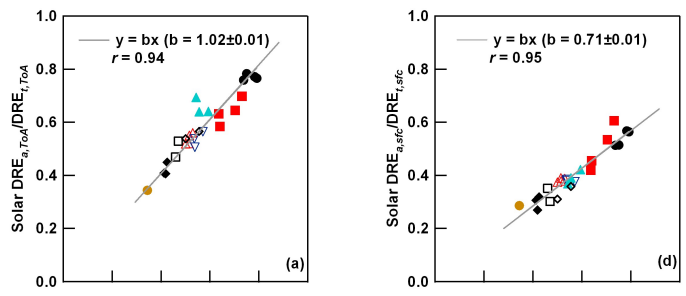

\section{ACPD}

9, 22539-22579, 2009
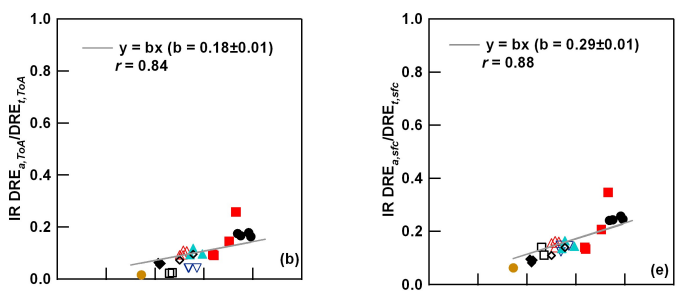

\section{Aerosol direct radiative forcing}

M. R. Perrone et al.
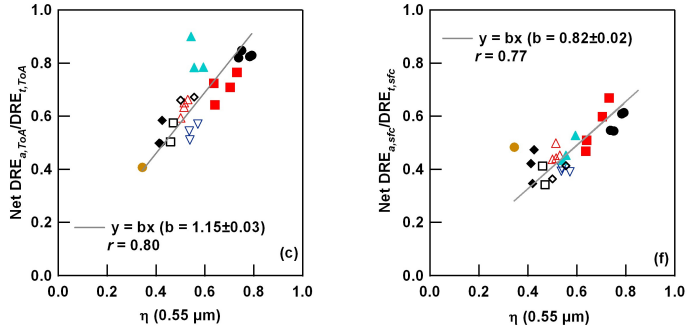

Title Page

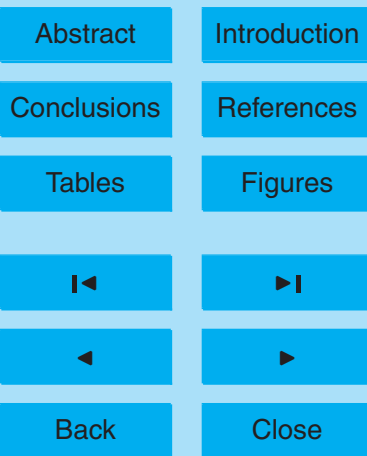

Full Screen / Esc

Fig. 15. Ratio of the DRE by anthropogenic particles $\left(D_{R} E_{a}\right)$ to the $D R E$ by all particles $\left(D^{2} E_{t}\right)$ as a function of the fine mode fraction $\eta$ at $0.55 \mu \mathrm{m}(\mathrm{a}-\mathrm{c})$ at the ToA and in the solar, IR, and solar+IR spectral range, respectively, (d-f) at the surface and in the solar, IR, and solar+IR spectral range, respectively. Different symbols are used to characterize different dusty-days: 17 July $2003(\bullet) ; 24$ July $2003(\triangle)$; 8 July $2004(\nabla) ; 5$ July $2005(\bullet) ; 6$ July 2005 (口); 18 July $2005(\triangle) ; 19$ June $2006(\diamond) ; 22$ June $2006(\square) ; 26$ June $2006(\diamond)$.

Printer-friendly Version

Interactive Discussion 